\title{
THE NEW JERSEY ALTERNATIVE PROGEDURE FOR DISPUTE RESOLUTION ACT: VANGUARD OF A "BETTER WAY"?*
}

\section{JOHN V. O'HARA广}

Early in this century, Judge Learned Hand reportedly remarked that he "would fear nothing save death or sickness as much as he would fear litigation."1 The intervening years from his time to our own have brought no relief from the frustration of pursuing a claim in court. For litigants, long delays and high costs characterize the traditional judicial process, ${ }^{2}$ while for judges there is mounting pressure to manage cases aggressively from initial filing to final disposition in order to control the growth of the civil docket. ${ }^{3}$ Only lawyers remain unper-

* See Burger, Isn't There A Better Way?, 68 A.B.A. J. 274, 276 (1982) (Chief Justice advocating increased use of arbitration to ease the burden on the courts).

† B.A. 1986, College of the Holy Cross; J.D. Candidate 1989, University of Pennsylvania.

1 Carrington, Adjudication As A Private Good: A Comment, 8 J. Legal Stud. 303, 304 (1979).

${ }^{2}$ See, e.g., R. Posner, The Federal Courts: Crisis and Reform 59-93 (1985) (examining the causes of the "explosion in federal judicial business that has taken place since . . 1960" through exhaustive statistical analysis); Civiletti, Zeroing in on the Real Litigation.Crisis: Irrational Justice, Needless Delays, Excessive Costs, 46 MD. L. REv. 40, 44-46 (1986) (a study of 18 general jurisdiction state trial courts found that $49 \%$ of tort cases took more than two years to resolve, and $10 \%$ took over four years); Edwards, The Rising Work Load and Perceived "Bureaucracy" of the Federal Courts: A Causation-Based Approach to the Search for Appropriate Remedies, 68 Iowa L. Rev. 871, 874-79, 927-36 (1983) (discussing aspects of the popular perception of a litigation explosion and proposing use of alternative forums); Faure, The Arbitration Alternative: Its Time Has Come, 46 MONT. L. REv. 199, 199 (1985) (noting the negative financial and emotional effect of litigation on litigants and discussing the need to conserve legal resources); Miller, The Adversary System: Dinosaur or Phoenix, 69 MinN. L. REv. 1, 9 (1984) (stating that the modern "pretrial structure permits artful attorneys to hide the ball and keep alive hopeless claims, as well as defenses, for a much longer time than was possible" under the old procedural system). But see Trubck, Sarat, Felstiner, Kritzer \& Grossman, The Costs of Ordinary Litigation, 31 UCLA L. REv. 72, 82-93, 123 (1983) [hereinafter Ordinary Litigation] (acknowledging serious efficiency problems with certain types of cases, but asserting that most ordinary litigation is cost-effective for the litigant).

3 Rule 16 of the Federal Rules of Civil Procedure was amended in 1983 "to codify and encourage the use of case management techniques." Peckham, A Judicial Response to the Cost of Litigation: Case Management, Two-Stage Discovery Planning and Alternative Dispute Resolution, 37 RuTGERS L. REv. 253, 258 (1985). Reactions to this procedural innovation have been mixed. Compare id. at 255-60 (discussing the utility of case management and noting its inevitable development from the advent of pretrial discovery) with Resnik, Managerial Judges, 96 HARv. L. REv. 374, 378 (1982) (pointing out the dangers of conferring upon courts this relatively uncircum- 
turbed: the United States has a larger bar and more lawyers per capita than any other country, and legal expenditures continue to increase at a rate that outpaces total economic growth. ${ }^{4}$ Yet, such uncontrolled growth is not likely to last. Only one percent of the nation's population-consisting primarily of corporations and wealthy individualsconsumes ninety-five percent of its legal services. ${ }^{5}$ The inefficiencies of traditional litigation threaten, as one commentator warned, to "kill the goose that produces the proverbial golden egg."

Given their community of interests, it is no wonder that courts, the bar, and potential litigants have been quick to embrace the various forms of alternative dispute resolution ("ADR") that promise streamlined procedures and shorter disposition time rather than the formalized combat of traditional civil litigation. ${ }^{7}$ Still, the growing ADR movement has not been without its critics, who argue that the pursuit of procedural benefits often carries dangerous substantive costs. While admitting that ADR usually achieves the utilitarian goal of rapid and efficient repose, these critics believe that, because of its lack of procedural safeguards, it should not replace traditional litigation to any significant degree. ${ }^{8}$

scribed extrajudicial power).

- See Ad Hoc Panel on Dispute Resolution and Public Policy, National Institute for Dispute Resolution, Paths to Justice: Major Public Policy Issues of Dispute Resolution 7-8 (1983) [hereinafter Paths to Justice]; see also Levin \& Colliers, Containing the Cost of Litigation, 37 Rutgers L. Rev. 219, 222-23 \& fig. 1 (1985) (demonstrating statistically that legal expenses are consuming an increasing portion of the nation's GNP).

- See Paths to Justice, supra note 4, at 7-8.

- Statement by Ronald M. Sturtz, Chairman, Equity Jurisprudence Committee, Essex County Bar Association, to the New Jersey Legislature 1 (Oct. 27, 1986) [hereinafter October Sturtz Statement] (on file with the University of Pennsylvania Law Review).

7 See, e.g., Shearson/American Express, Inc. v. McMahon, 107 S. Ct. 2332, 2337 (1987) (asserting that the FAA establishes a "federal policy favoring arbitration" requiring that agreements to arbitrate be "rigorously enforce[d]"); Edwards, Alternative Dispute Resolution: Panacea or Anathema?, 99 HARv. L. REv. 668, 673 (1986) (noting the rapid adoption of court-annexed arbitration in many state and federal courts); Meyerowitz, The Arbitration Alternative, 71 A.B.A. J. 78, 79 (1985) (the number of commercial and labor disputes arbitrated under American Arbitration Association rules doubled between 1975 and 1985); Middleton, Burger: Arbitrate More and Litigate Less, 68 A.B.A. J. 257, 257 (1982) (Chief Justice Burger expressing strong support for the use of arbitration).

${ }^{8}$ See, e.g., PATHS To JuSTICE, supra note 4, at 10,13 (courts "are the appropriate forum when the purpose is to establish a societal norm or legal precedent," because arbitration frequently sacrifices quality for efficiency in decisionmaking); Bayer \& Abrahams, The Trouble With Arbitration, 11 LiTIGATION 30, 30 (1985) ("consistency and predictability are not characteristics of arbitration"); Brunet, Questioning the Quality of Alternative Dispute Resolution, 62 TUL. L. REv. 1, 54 (1987) (the procedural value of ADR may come at the expense of substantive law); Edwards, supra note 7 , at 676 (proponents of ADR need to consider the dangers of broadening its scope to 
Although there are several popular methods of ADR, including mediation, ${ }^{9}$ negotiation, ${ }^{10}$ and the minitrial, ${ }^{11}$ arbitration is distinguishable from these because it more closely resembles litigation. Generally touted as speedier, less costly, and more amicable than conventional litigation, arbitration is growing rapidly in popularity; presently, more commercial claims are arbitrated than are tried before a jury. ${ }^{\mathbf{1 2}}$

Despite this popularity, in February 1987, the New Jersey Legislature enacted the New Jersey Alternative Procedure For Dispute Resolution Act ("NJADR Act") 13 in response to growing dissatisfaction with the arbitration process. The NJADR Act seeks to combine the advantages of litigation and arbitration, creating a cost-efficient system that also ensures that some measure of procedural regularity will be available to those who use it. On the federal level, a bill proposing a similar ADR system was introduced in Congress in June 1987 and is currently under consideration by the House Judiciary Committee. ${ }^{14}$ It is expected that the so-called Federal Alternative Procedure for Dispute

encompass types of disputes more properly resolved by adjudication); Fiss, Against Settlement, 93 YALE L.J. 1073, 1075 (1984) (attacking the assumptions of the ADR movement within the context of settlements and calling for sharp limitations on the use of ADR); Resnik, Failing Faith: Adjudicatory Procedure in Decline, 53 U. CHr. L. REv. 494, 544-46 (1986) (the emphasis on ADR's speed and low cost ignores the safeguards that courts provide); Terrell, Rights and Wrongs in the Rush to Repose: On the Jurisprudential Dangers of Alternative Dispute Resolution, 36 EMORY L.J. 541, 552 (1987)("the remedial outcome is . . . so important [to proponents of ADR] that rules and rights as traditionally understood nearly fade from their view altogether"); Lasersohn, Arbitration Seems Appealing, but Has Myriad Pitfalls, N.Y. Times, Oct. 5, $1986, \S 11$, at 28, col. 1 (arbitration lacks predictability, checks and balances, and effective review).

- Mediation may be defined as "[t]he process by which participants, together with the assistance of a neutral person or persons, systematically isolate disputed issues in order to develop options, consider alternatives, and reach a consensual settlement that will accomodate their needs." Domke on Commercial. ARBITRation $\S 3: 15$ (G. Wilner rev. ed. 1984) (Practice Guide) [hereinafter Commercial Arbitration].

${ }^{10}$ Negotiation may be defined as "[t]he process of engaging in good faith efforts to reach an agreement or resolve a dispute, through the confidential exchange of factual statements and representations." Id. $\S 3: 13$ (Practice Guide).

11 The minitrial is " $[\mathrm{a}]$ means to resolve litigation between corporations expeditiously and economically by providing a forum for a fight on the issues staged in private before the real decision-makers." Id $\$$. 3:21 (Practice Guide). It is intended to encourage settlement by allowing the parties to evaluate the relative strength of their arguments in an informal, nonbinding procedure prior to trial. See id. (Practice Guide).

12 See American Arbitration Association, Backgrounder: Facts About Arbitration (Sept. 15, 1987); see also Green, Corporate Alternative Dispute Resolution, 1 Oнго ST. J. ON Dispute Resolution 203, 270 (1986) ("[A]rbitration is still considered by many institutional litigants as the primary dispute resolution alternative. . . . Moreover, most studies show that arbitration continues to be faster and less expensive than adjudication.").

13 N.J. Stat. ANN. §§ 2A:23A-1-23A-19 (West 1987).

14 See 1 Alternative Dispute Resolution Rep. (BNA) 131 (July 9, 1987). 
Resolution Act of 1987 ("FADR Act"), ${ }^{16}$ if passed, would likely form the basis of a model act of the Commissioners on Uniform Laws. ${ }^{16}$ In New Jersey and at the federal level, the new ADR system would not replace existing procedures, but rather would serve as another option that parties may choose as they plan for dispute resolution.

This Comment evaluates the new dispute resolution procedures created by the NJADR Act both as the synthesis of responses to popular arguments for and against alternative dispute resolution, and as the precursor of similar statutes at the federal and state levels. The issues addressed are of pressing concern: criticism of the ADR movement has increased in recent years, ${ }^{17}$ yet the sense of institutional crisis afflicting the courts has never been more profound. ${ }^{18}$ The scope of this Comment will be limited to the commercial arbitration context because, while such arbitration closely resembles litigation in form, its informality and articulated goal of achieving repose ${ }^{\mathbf{1 9}}$ as quickly and inexpensively as possible is shared by all forms of ADR. ${ }^{20}$

Part I of this Comment discusses the arbitration process in commercial cases. The discussion encompasses a description of the statutory and judicial treatment of arbitration past and present, a synopsis of common arbitration procedure, and an examination of the asserted benefits of arbitration. Part II compares the relative costs and benefits of arbitration and litigation, with particular consideration of their practi$\mathrm{cal}$ and the jurisprudential aspects. To illustrate the theoretical points made in this discussion, Part II concludes with a case study of a major commercial dispute recently resolved by arbitration. The goal is to demonstrate that although arbitration offers many practical efficiencies, it also presents jurisprudential inefficiencies. Specifically, the rapid repose promised by arbitration is often achieved at the expense of the vindication of public rights. Part III evaluates the NJADR Act as a means of dispute resolution by comparing it with the conventional methods of commercial arbitration and litigation. This Comment concludes that, despite some shortcomings, the procedural format of the NJADR Act presents a respectable response to the ADR debate, and

16 H.R. 2721, 100th Cong., 1st Sess. (1987).

${ }^{16}$ See Lasersohn, supra note $8, \S 11$, at 28 , col. 1; Statement by Ronald M. Sturtz, Chairman, Equity Jurisprudence Committee, Essex County Bar Association, to New Jersey Legislature 3 (June 5, 1986) [hereinafter June Sturtz Statement] (on file with the University of Pennsylvania Law Review).

17 See infra notes 72-78 and accompanying text.

18 See infra notes 79-90 and accompanying text.

19 For the purposes of this Comment, repose may be defined as the resolution of a dispute, without regard to the means employed.

${ }_{20}$ See Terrell, supra note 8 , at 547-48. 
one that may satisfy equally both court administrators and jurisprudential scholars.

\section{A General Overview of Commercial Arbitration}

\section{A. History}

Arbitration is the submission of a dispute by the parties involved to one or more impartial persons for a final and binding decision issued after a hearing at which both parties have had an opportunity to be heard. ${ }^{21}$ It has a long history as a means of dispute resolution, but, until recently, judicial attitudes toward arbitration have been rather ambivalent. ${ }^{22}$ At common law, courts rarely enforced agreements to arbitrate, because arbitration was thought to "oust" the jurisdiction of the courts. ${ }^{23}$ When one considers that early English judges were dependent upon filing fees for their salaries, the origin of this hostility is easy to understand. ${ }^{24}$ This judicial attitude, transported intact to the United States, was so slow to change ${ }^{25}$ that legislatures were forced to intervene and provide explicitly for judicial enforcement of contractual arbitration agreements. In 1925 Congress passed the United States Arbitration Act, ${ }^{26}$ commonly known as the Federal Arbitration Act

21 See Black's Law Dictionary 96 (5th ed. 1979). For a succinct comparison of arbitration and litigation, see Commercial ARBITration, supra note 9, § 1:01 (Practice Guide).

${ }_{22}$ See Commercial Arbitration, supra note 9, $\S \S 2: 01-06$ (Practice Guide); Fletcher, Privatizing Securities Disputes Through the Enforcement of Arbitration Agreements, 71 MinN. L. REv. 393, 393 (1987); see also Faure, supra note 2, at 201 (arbitration "was in use many centuries before the beginning of English common law"); Mann, The Formalization of Informal Law: Arbitration Before the American Revolution, 59 N.Y.U. L. REv. 443, 451-68 (1984) (describing the use and gradual formalization of arbitration in Connecticut in the mid-seventeenth to mid-eighteenth centuries); Mentschikoff, Commercial Arbitration, 61 Colum. L. REv. 846, 854-56 (1961) (tracing the origins of arbitration back to the thirteenth century).

${ }^{23}$ For a discussion of the "ouster" concept, see, e.g., Kulukundis Shipping Co., S/A v. Amtorg Trading Co., 126 F.2d 978, 985 (2d Cir. 1942) (tracing the development of ouster in English common law and noting its adoption by American courts).

24 See id. at 983 n.14; Landes \& Posner, Adjudication as a Private Good, $8 \mathrm{~J}$. LEGal. STUD. 235, 241 (1979).

${ }^{25}$ See, e.g., Tobey v. County of Bristol, 23 F. Cas. 1313, 1321 (C.C.D. Mass. 1845) (No. 14,065) (Story, J.) ("[Arbitrators] are not ordinarily well enough acquainted with the principles of law or equity [] to administer either effectually, in complicated cases; and hence it has often been said, that the judgment of arbitrators is but rusticum judicium.").

${ }^{26}$ United States Arbitration Act, ch. 213, 43 Stat. 883 (1925) (codified as amended at 9 U.S.C. $\$ \S 1-14(1982))$. Congress enacted title 9 of the U.S. Code with the Act of July 30,1947, ch. 392, 61 Stat. 669, entitled "Arbitration," which repealed the name "United States Arbitration Act," see id. § 14, 61 Stat. at 674. The FAA was intended to "revers[e] centuries of judicial hostility to arbitration agreements." Scherk v. Alberto-Culver Co., 417 U.S. 506, 510 (1974). 
("FAA"), ${ }^{27}$ and today almost every state has enacted some sort of arbitration legislation. ${ }^{28}$

The federal courts were reluctant to follow this explicit expression of legislative policy, but gradually the historic judicial mistrust of the arbitration process gave way to a more tolerant attitude. ${ }^{29}$ In recent years the Supreme Court has repeatedly enforced agreements to arbitrate, even in cases involving antitrust or other statutory claims. ${ }^{30} \mathrm{Al}-$ though enforcement policies in state courts vary under state statutes, the Court's decision in Southland Corporation v. Keating ${ }^{31}$ made it clear that the FAA expressed a national policy favoring arbitration and "withdrew the power of the states to require a judicial forum for the resolution of claims which the contracting parties had agreed to resolve by arbitration." ${ }^{\mathbf{3 2}}$ Consequently, as long as an arbitration clause is itself valid, ${ }^{33}$ the agreement to arbitrate will be enforced by the courts.

\section{B. Procedure}

In most arbitrations, the parties have agreed in advance through a contractual arbitration clause to resolve their disputes in this alternative forum. Such a clause typically will provide for the arbitration of "[a]ny controversy or claim arising out of or relating to this contract, or the

${ }^{27}$ See, e.g., Perry v. Thomas, 107 S. Ct. 2520, 2523 (1987); Southland Corp. v. Keating, 465 U.S. 1, 5 (1984).

${ }_{28}$ See Special Project, Self-Help: Extrajudicial Rights, Privileges and Remedies in Contemporary American Society, 37 VAND. L. REV. 845, 935 (1984) (noting that every state except Vermont has adopted arbitration legislation closely resembling the Uniform Arbitration Act); see also UNIF. ARBITRATION ACT, 7 U.L.A. 1 (1985 \& Supp. 1987) (listing 30 states as having adopted the UAA). But see Vermont Arbitration Act, VT. Stat. ANN. tit. 12, §§ 5651-5681 (1973 \& Supp. 1986).

29 Compare Robert Lawrence Co. v. Devonshire Fabrics, Inc., 271 F.2d 402, 40607 (2d Cir. 1959) (enforcing the FAA), cert. dismissed, 364 U.S. 801 (1960) with Hurst v. Litchfield, 39 N.Y. 377,379 (1868) (holding that a contractual stipulation providing for arbitration of all disputes was not binding at common law).

${ }_{30}$ See, e.g., Perry, $107 \mathrm{~S}$. Ct. at 2526 (under the Supremacy Clause, the FAA preempts a state law requirement of a judicial forum); Shearson/American Express, Inc. v. McMahon, 107 S. Ct. 2332, 2343, 2345-46 (1987) (RICO claims and claims under $\S 10(\mathrm{~b})$ of the Securities Exchange Act of 1934 held arbitrable under a predispute arbitration agreement); Mitsubishi Motors Corp. v. Soler Chrysler-Plymouth, Inc., 473 U.S. 614, 629 (1985) (the arbitration clause of an international sales agreement requires arbitration of antitrust claims); Dean Witter Reynolds Inc. v. Byrd, 470 U.S. 213, 217 (1985) (the FAA requires district courts to compel arbitration of pendent state law claims upon a motion to compel).

31465 U.S. 1 (1984).

32 Id. at 10.

33 For a discussion of the elements of a valid arbitration clause, see CoMmercial ARBItRation, supra note 9, §§ 5:00-7:02. See also 9 U.S.C. $\S 2$ (1982) (stating that all arbitration agreements under the statute are valid and enforceable unless otherwise provided at law or, in equity). 
breach thereof." 34 To further the policy of enforcing agreements to arbitrate, ${ }^{35}$ the courts will interpret broadly the scope of the arbitration clause; unless the claim alleges fraud in the inducement of the arbitration clause itself, it must be submitted to arbitration. ${ }^{36}$ Even disputes as to the scope of the arbitration clause, or a claim that the entire contract was fraudulently induced, must be arbitrated. ${ }^{37}$

The arbitration clause usually specifies the source of the rules under which the dispute is to be resolved. Arbitration procedures vary because they are administered by a number of entities, such as securities and commodities exchanges, trade associations, and the American Arbitration Association ("AAA"). Since the AAA is "the leading agency for the administration of every type of arbitration," 38 this Comment will use its commercial arbitration rules to represent those of commercial arbitration generally. ${ }^{39}$

Under AAA rules, a party initiates the dispute resolution process by filing a written demand for arbitration with the Association and serving a copy on the offending party by mail. ${ }^{40}$ The standard AAA Demand for Arbitration Form gives little information as to the nature of the claim, leaving only one inch of space in which to state it. ${ }^{41}$ Thus, right from the beginning, the arbitration process streamlines those procedures employed in conventional litigation.

After the claim (and any counterclaim) has been filed and shown

s4 Commercial ARbitration, supra note 9, § 4:20 (Practice Guide).

ss The FAA has been interpreted by the Supreme Court as having established a "federal policy favoring arbitration." Moses H. Cone Memorial Hosp. v. Mercury Constr. Corp., 460 U.S. 1, 24 (1983).

${ }^{36}$ This is a statement of the so-called "Prima Paint Rule" articulated by the Supreme Court. See Prima Paint Corp. v. Flood \& Conklin Mfg. Co., 388 U.S. 395, 402 (1967) (applying the FAA); see also Schneider, Inc. v. Research-Cottrell, Inc., 474 F. Supp. 1179, 1185 (W.D. Pa. 1979) (following Prima Paint); Quirk v. Data Terminal Sys., Inc., 400 N.E.2d 858, 861 (Mass. 1980) (applying the Prima Paint rule under a state arbitration statute). The NJADR Act incorporates the Prima Paint rule in $\S 5$. See The New Jersey Alternative Procedure for Dispute Resolution Act, ch. 54, 1987 N.J. Laws 68 (codified at N.J. STAT. ANN. § 2A:23A-5).

${ }^{37}$ See Prima Paint, 388 U.S. at 402.

38 Commercial ARBITration, supra note 9, § 2:02; see also Coulson, Arbitration in the Eighties: How to Make it Work for You, 17 Forum 673, 673 (1982) ("[T]he major [arbitration] systems in the United States are administered by the AAA.").

30 AAA officials have publicly criticized New Jersey's adoption of the NJADR Act. See, e.g., Naiman, New Dispute System Combines Arbitration, Courts, N.J.L.J., June 12, 1986, at 3, 3 (AAA regional director describing NJADR Act's procedures as unnecessary and "attorney-oriented"); Chambers, Streamlining Arbitration No Easy Matter, Asbury Park Press, Oct. 5, 1986, at A1, col. 1, A20, col. 2 (AAA president asserting that arbitration alone is sufficient to handle cases).

10 See American Arbitration Association, Commercial, Arbitration Rule 7 (1986) [hereinafter AAA].

41 See Bayer \& Abrahams, supra note 8, at 31. 
to be arbitrable, ${ }^{42}$ the AAA, with input from the parties, chooses the arbitrator or arbitrators. The AAA maintains a roster of arbitrators who are experts in particular fields, as well as biographies of each to be made available to the parties. After it is contacted by the parties, the AAA sends each side a list of potential arbitrators, from which the parties strike off those they find objectionable. Each list is then returned to the AAA, which chooses a mutually acceptable arbitrator or panel. ${ }^{43}$ The president of the AAA has noted that "[s]electing an arbitrator is the most critical step in arbitration."

The principal value of arbitration is said to reside in the procedures that operate between the initial filing and the final award. Although there is no requirement that they do so, most parties choose to be represented by legal counsel. ${ }^{45}$ AAA procedural rules are quite simple, and generally remain so despite the parties' freedom to make them more complex by mutual agreement. For example, AAA rules do not explicitly provide for pretrial discovery, but the parties may agree between themselves to cooperate and exchange information. ${ }^{46} \mathrm{~A}$ major break with the formality of a trial is the lack of either common law or statutory rules of evidence. ${ }^{47}$

The actual hearing is conducted privately, and no transcript is kept unless the parties request and pay for it. ${ }^{48}$ The conduct of the hearing superficially resembles a trial: each side may make an opening statement, present its case, and cross-examine hostile witnesses. ${ }^{49}$ The hearing room atmosphere, however, is decidedly less formal than the

42 Although exploration of the issue is beyond the scope of this Comment, the arbitrability of a claim may itself be disputed by the parties. See, e.g., Brenner, Arbitration: Compulsion and Avoidance, 17 ForUM 656, 657-64 (1982) (providing a good discussion of disputes over whether a claim is arbitrable under the FAA).

4see AAA, supra note 40, Rule 13.

14 Coulson, supra note 38, at 673; see also Landes \& Posner, supra note 24, at 245-46 ("T T]he problem of selection makes arbitration a virtually unusable method of dispute resolution where there is no preexisting contractual or other relationship between the disputants.").

t5 See AAA, supra note 40, Rule 22.

16 See AAA, supra note 40, Rule 31 (giving the arbitrator the power to subpoena documents or witnesses either at the request of a party or on her own initiative, if the law of the jurisdiction permits). Since the parties are adversaries, they may not wish to exchange information voluntarily. See Bayer \& Abrahams, supra note 8, at 31 . Effective discovery cannot be accomplished through voluntary disclosure by the parties. See Brazil, The Adversary Character of Civil Discovery: A Critique and Proposals for Change, 31 VAND. L. REv. 1295, 1299 (1978) ("Minimal reflection reveals a fundamental antagonism between the goal of truth through disclosure and the protective and competitive impulses that are at the center of the traditional adversary system of dispute resolution.").

17 See AAA, supra note 40, Rule 31.

48 See AAA, supra note 40, Rule 23.

49 See AAA, supra note 40, Rule 29. 
solemnity of the courtroom..$^{50}$

The award itself must be written ${ }^{51}$ and submitted within thirty days of the hearing's conclusion..$^{62}$ The award need not be accompanied by an opinion explaining findings of fact and conclusions of law, and usually is not. ${ }^{53}$ Thus, the arbitrator is free to decide the claim and fashion a remedy according to her own sense of fairness. After the award is made, the prevailing party may then have it enforced by a court of proper jurisdiction. ${ }^{54}$ Review is extremely deferential; a court will generally uphold the award unless the arbitrator has grossly abused her powers ${ }^{\mathrm{bS}}$ or there is some evidence that the arbitration award was fraudulently induced. ${ }^{56}$

\section{G. The Advantages of Arbitration}

Parties selecting ADR mechanisms generally, and arbitration in particular, are most interested in rapid and efficient dispute resolution. ${ }^{57}$ Other purported benefits include a private forum that avoids unwelcome publicity, ${ }^{88}$ preservation of good will between the parties ${ }^{58}$ the specialized expertise of the arbitrator in the subject matter of the dispute, ${ }^{60}$ and freedom from being bound by established rules of law in resolving the dispute and designing a remedy. ${ }^{61}$ Arbitration is a sensible and convenient alternative for contracting parties, such as management and labor, or a contractor and subcontractors, who are anticipating a

so See Bayer \& Abrahams, supra note 8 , at 31.

BI See AAA, supra note 40, Rule 42.

52 See AAA, supra note 40, Rule 41.

53 See AAA, supra note 40, Rule 42. In fact, the AAA actively discourages arbitrators from making written decisions, because they would facilitate subsequent attacks upon the award by the losing party. See R. Coulson, Business ArbitraTION-What You NeEd To KNow 26 (3d ed. 1986); Bayer \& Abrahams, supra note 8, at 32; see also Landes \& Posner, supra note 24, at 248 (written decisions in an arbitration are not economically efficient).

st See AAA, supra note 40, Rule 47(c).

ss See 9 U.S.C. $\$ \S 10(c)-10(d)$ (1982); UNIForm ARBITRATION ACT $\S 12(a)(3)$, 7 U.L.A. 140 (as amended 1968); Commercial ARBitration, supra note 9, § 34.01.

${ }^{86}$ See 9 U.S.C. § 10(a)-(d) (1982); UnIFORM Arbitration ACT $\S 12,7$ U.L.A. 140 (as amended 1968); Commercial ARBITRation, supra note 9, §§ 34:01-02; see also PATHS To JUSTICE, supra note 4, at 13 ("The award in binding arbitration usually is enforceable by a court with little or no review.").

${ }_{57}$ See Commercial Arbitration, supra note 9, $\S 4.01$ (Practice Guide).

${ }^{58}$ See id. (Practice Guide).

60 See id. (Practice Guide).

${ }^{60}$ See id. \$ 2:01; see also Fuller, The Forms and Limits of Adjudication, 92 HARv. L. Rev. 353, 391 (1978) ("By and large ... the decisions of our courts in commercial cases do not represent adjudication at its highest level. The reason is a lack of judicial 'feel' for the problems involved.").

${ }^{61}$ See Commercial ARbitration, supra note 9, $\S 2 ; 01$. 
number of routine disputes during the term of their agreement. ${ }^{62}$

While the informality of the hearing readily achieves the primary goals of speed and low cost, several other provisions are important complements to meeting these goals. For example, having a dispute resolved by an expert in the industry to which the controversy relates saves the time and expense involved in educating a generalist judge or jury in the subject matter of the dispute. ${ }^{83}$ In addition, dispute resolution through arbitration should generate fewer appeals, in part because judicial policies favor limited review and the enforcement of arbitration awards, and in part because arbitrators need not apply law correctly or issue a written opinion. The disappointed party and any reviewing court are thereby rendered ignorant of the grounds for appeal. As a result, a party choosing arbitration can expect greater finality from the arbitrated decision, reducing the likelihood of expensive and time-consuming appellate procedures. ${ }^{64}$

The relaxed procedural rules also preclude burdensome pretrial strategizing and manuevering, permitting the parties to focus on the substantive issues. By eliminating extensive discovery, arbitration removes a primary source of frustration for both commercial litigants and trial judges. ${ }^{65}$ Many of the destructive effects of litigation upon

62 Some commentators take the extreme view that ADR is absolutely superior to litigation. See, e.g., McThenia \& Shaffer, For Reconciliation, 94 YALE L.J. 1660, 1664 (1985) (the ADR movement rests on values of religion, community, and workplace); Menkel-Meadow, For and Against Settlement: Uses and Abuses of the Mandatory Settlement Conference, 33 UCLA L. REv. 485, 487 (1985) ("the quality of dispute resolution is improved when models other than formal adjudication are used"); see also PATHS To JUSTICE, supra note 4 , at 8 (There is hope that ADR "will provide more satisfying means to justice for a larger portion of the population."). But see Abel, Informalism: A Tactical Equivalent to Law?, 19 Clearinghouse Rev. 375, 383 (1985) ("Informalism is not an equivalent to law, either tactically or morally.").

${ }^{63}$ See R. Coulson, supra note 53, at 9; Faure, supra note 2, at 206; Solove, Alternative Means To Resolve Corporate Disputes: A Survey, 91 CoM. L.J. 133, 137 (1986).

${ }^{\text {B4 }}$ But see infra text accompanying notes $214-15$ (noting that the procedural advantages of arbitration are frequently illusory when the defeated party appeals).

${ }_{65}$ See e.g., Brazil, Views from the Front Lines: Observations by Chicago Lawyers About the System of Civil Discovery, 1980 AM. B. Found. REs. J. 217, 233-34 ("Even litigators who frankly admitted that they were becoming wealthy primarily because of fees attributable to discovery expressed amazement and concern about the rapid escalation of the expense of conducting and complying with discovery."); Levin \& Colliers, supra note 4, at 231-32 (placing much of the blame for rising legal expenses on discovery); Miller, supra note 2 , at 9 (characterizing discovery as "a debilitating and often interminable process"); Resnik, supra note 8 , at 542 (describing lawyers and judges as "[b]ored with the tedium of writing, answering, and ruling upon discovery requests").

The additional cost and delay related to the discovery process do not necessarily result from abusive tactics by attorneys. See Levin \& Colliers, supra note 4 , at 234 (studies show that discovery abuse is not common at either the state or federal court level). 
business relationships probably stem from use of discovery as a weapon of obfuscation. Therefore, if the parties are involved in a long-term and profitable contractual relationship, they may sensibly want to avoid these potentially harmful effects by choosing the arbitration forum. ${ }^{86}$

Finally, the parties usually perceive the results of arbitration as fair. ${ }^{67}$ One reason for this is the arbitrator's ability to fashion a compromise remedy, granting the prevailing party less than might have been received in court, thereby reducing the sting of the adverse judgment on the losing party. ${ }^{68}$ As long as the arbitrator does not need to justify legally her decision, she is free to fashion this sort of compromise. In the end, both parties realize some degree of satisfaction and will return to the arbitration forum in the future.

The policies presently broadening the range of arbitrable claims and the enforcement of agreements to arbitrate ${ }^{69}$ are not antithetical to the judicial process. There is a demand and a need for this alternative forum, as there has been for hundreds of years: arbitration settles many disputes as quickly, quietly, and painlessly as possible. But a growing number of observers have recognized that arbitration and litigation are not interchangeable means of dispute resolution, and that to treat them as such when particular types of claims are involved is dangerous. ${ }^{70}$ The procedural benefits are clear, but the substantive costs are only beginning to become obvious.

\section{Comparative Analysis of Process Choice}

A number of commentators have advocated the substitution of ADR procedures, whenever possible, to relieve the bursting dockets and rising costs of traditional litigation. Their advocacy is fueled by a concern for both efficiency and quality of resolution. ${ }^{71}$ The legal community generally accepts the need for an alternative forum for dispute resolution, and the claim that many disputes can be disposed of adequately outside the judicial system. More recently, however, other commenta-

6B Paradoxically, informality may have the effect of causing future disputes. See Fuller, supra note 60, at 388 ("[W] here a decision enters into some continuing relationship, if no reasons are given the parties will almost inevitably guess at reasons and act accordingly."). Thus, while arbitration may reduce or eliminate the antagonisms of litigation, it could be inefficient in the long run by failing to alter the type of behavior that led to the breakdown.

67 See Lieberman \& Henry, Lessons from the Alternative Dispute Resolution Movement, 53 U. CHI. L. REv. 424, 429-31 (1986).

68 See Solove, supra note 63, at 137. nying text.

${ }^{69}$ See supra notes 29-33 and accompanying text; infra notes 79-92 and accompa-

70 See infra notes 74-78 and accompanying text.

71 See supra notes 57-65 and accompanying text. 
tors have begun to express wariness at the fervency and scope of the ADR movement. ${ }^{72}$ While acknowledging that ADR serves an important function as a safety valve for frustrated litigants and an overburdened judicial system, these commentators argue with increasing stridency that the attributes and safeguards of court adjudication are unmatched by any existing system of ADR. ${ }^{73}$

Indeed, no rational argument in favor of ADR can deny the vital function that traditional litigation fulfills in society. ${ }^{74}$ When disputes involve issues of legal or constitutional interpretation, or public rights, ${ }^{75}$ formal adjudication should be the only valid form of resolution. A paradox is revealed when private rights are implicated. Although courts are necessary to protect private rights, and the judicial system depends on private litigants to pursue these rights, ${ }^{76}$ long delays and high costs may

72 See, e.g., Paths of Justice, supra note 4, at 10, 13 (courts "are the appropriate forum when the purpose is to establish a societal norm or legal precedent," because arbitration frequently sacrifices quality for efficiency in decisionmaking); Bayer \& Abrahams, supra note 8, at 30 ("consistency and predictability are not characteristics of arbitration"); Terrell, supra note 8, at 552 ("[T]he remedial outcome is . . . so important [to ADR proponents] that rules and rights as traditionally understood nearly fade from their view altogether."). Edward Brunet terms these advocates "Second Wave" commentators. Brunet regards the Second Wave as more "balanced and skeptical[,] . . . . focus[ing] upon the positive and negative attributes of litigation and of various ADR mechanisms." Brunet, supra note 8 , at 4 . On the other hand "the First Wave commentary emphasizes only the favorable characteristics of ADR and eschews moderate viewpoints that may acknowledge positive commentary regarding traditional litigation." Id.

${ }^{73}$ See Brunet, supra note 8, at 3-4; see also Stroh Container Co. v. Delphi Indus., 783 F.2d 743, 751 n.12 (8th Cir.) ("The present day penchant for arbitration may obscure for many parties who do not have the benefit of hindsight that the arbitration system is an inferior system of justice, structured without due process, rules of evidence, accountability of judgment and rules of law."), cert. denied, 476 U.S. 1141 (1986).

${ }^{74}$ The purpose of adjudication "is not to maximize the ends of private parties, nor simply to secure the peace, but to explicate and give force to the values embodied in authoritative texts such as the Constitution and statutes: to interpret those values and to bring reality into accord with them." Fiss, supra note 8 , at 1085; see also Edwards, supra note 7, at 676 ("An oft-forgotten virtue of adjudication is that it ensures the proper resolution and application of public values.").

75 "Public policy should be invoked to prevent arbitration when at issue is a legislative expression or a basic case law principle designed for some purpose other than to foster justice between the parties to the dispute." Sterk, Enforceability of Agreements to Arbitrate: An Examination of the Public Policy Defense, 2 Cardozo L. REv. 481, 483 (1981) (footnote omitted); see also Kanowitz, Alternative Dispute Resolution and the Public Interest: The Arbitration Experience, 38 HAstings L.J. 239, 257, 261 (1987) (describing the tension between public policies and the policies favoring arbitration).

${ }^{76}$ The antitrust laws provide a good example of such reliance. In American Safety Equip. Corp. v. J.P. Maguire \& Co., 391 F.2d 821 (2d Cir. 1968), the court stated that "a claim under the antitrust laws is not merely a private matter. The Sherman Act is designed to promote the national interest in a competitive economy; thus, the plaintiff asserting his rights under the Act has been likened to a private attorney-general who protects the public's interest." Id. at 826. The Supreme Court rejected this rationale in Mitsubishi Motors Corp. v. Soler Chrysler-Plymouth, Inc., 473 U.S. 614, 629 (1985), 
render the courts inaccessible, and therefore incapable of effectively performing this enforcement function. ${ }^{77}$ Arbitration may provide an accessible and efficient forum for dispute resolution, but its procedural advantages may mask some serious substantive shortcomings. Against the considerable weight of legislative policy and judicial opinion, scholars have rightfully begun to question a balance that accords more weight to expeditious repose than to the quality of justice dispensed. ${ }^{78}$

The following discussion assesses these comparative criticisms. To illustrate the difficulties of balancing procedural and substantive concerns while maintaining the positive aspects of ADR, this Part concludes with an examination of a recent commercial arbitration decision between two of the world's largest corporations.

\section{A. Process Choice: A Matter of Pragmatism or Misapprehension?}

\section{The Myth of the Litigation Explosion}

A party may choose an arbitration forum for a variety of reasons, ${ }^{79}$ the most common reason, however, is to avoid the much-discussed, yet ill-perceived, "crisis in the courts."80 State and federal courts are becoming increasingly backlogged, ${ }^{81}$ inflicting upon litigants

albeit in the context of an international antitrust dispute. The Mitsubishi Court recognized the public function of the antitrust laws, but argued that the primary purpose of a cause of action under the laws was compensatory. See id. at 634-37. A comprehensive discussion of this area of the law is beyond the scope of this Comment.

The concept of the private attorney general has been noted by the Supreme Court in other contexts. See, e.g., Fortner Enters. v. United States Steel Corp., 394 U.S. 495, 502 (1969) (private attorneys-general vindicate important societal interests as well as their own private concerns); Newman v. Piggie Park Enters., 390 U.S. 400, 401-02 (1968) (per curiam) (same); see also Civil Rights Attorneys' Fees Awards Act of 1976, 42 U.S.C. $\S 1988$ (1982) (awarding fees to victorious plaintiffs to encourage the enforcement of important public policies).

${ }_{77}$ See PATHS TO JUSTICE, supra note 4 , at 9.

78 See Bush, Dispute Resolution Alternatives and the Goals of Civil Justice: Jurisdictional Principles for Process Choice, 1984 Wrs. L. REv. 893, 990; see also Bayer \& Abrahams, supra note 8 , at 30 ("consistency and predictability are not characteristics of arbitration.").

${ }^{79}$ See supra notes $57-68$ and accompanying text.

so See Paths to Justice, supra note 4, at 7; Alschuler, Mediation with a Mugger: The Shortage of Adjudicative Services and the Need for a Two-Tier Trial System in Civil Cases, 99 Harv. L. Rev. 1808, 1817-20 (1986); Barton, Behind the Legal Explosion, 27 Stan. L. REv. 567, 567-84 (1975); Bush, supra note 78, at 895; Edwards, supra note 2, at 872-79, 897 (1983); Friedman, The Six Million Dollar Man: Litigation and Rights Consciousness in Modern America, 39 MD. L. REv. 661, 66170, 676-77 (1980); Galanter, Reading the Landscape of Disputes: What We Know and Don't Know (And Think We Know) About Our Allegedly Contentious and Litigious Society, 31 UCLA L. Rev. 4, 37 (1983); Manning, Hyperlexis: Our National Disease, 71 NW. U.L. REV. 767, 767-70 (1977).

81 See Paths to Justice, supra note 4, at 7; Edwards, supra note 2, at 877. 
both emotional frustration and financial loss, but commentators have mistakenly placed the blame upon an overly litigious society and a concomitant "litigation explosion."

Statistics show that between 1960 and 1983 the number of filings per capita in federal district courts tripled, ${ }^{\mathbf{8 3}}$ which may suggest that people have become more willing and able to assert their rights in court. ${ }^{84}$ On the other hand, the increase is quite reasonable given the immense social and technological changes in this country over that period. $^{85}$ Moreover, while the number of filings has grown, the number of cases actually litigated has remained constant with the rate of population growth. ${ }^{86}$

The sense of institutional crisis said to be enveloping the judicial system is not so much a problem of excessive litigiousness or immense

Current statistics indicate that the strain upon judicial resources in the federal courts is easing. In 1986, civil filings in the districts courts declined $13 \%$, to the lowest level since 1982 , and the rate of increase in the filing of appeals in the circuit courts also slowed. See Admininstrative Office of the U.S. Courts, Report of the Proceedings of THE Judicial CoNFERENCE of THE UNITEd States 4 (1987) [hereinafter JudiCIAl Conference Report].

${ }_{82}$ See, e.g., Galanter, supra note 80 , at 61 (the widespread perception of a litigation explosion is skewed by input from elite academic, practitioner, and federal judicial positions); Howard, Our Litigious Society, 38 S.C.L. REv. 365, 366-67 (1987) (studies of pre-twentieth century American urban and rural areas indicate significantly more litigiousness than exists today).

83 See R. PosNer, supra note 2, at 63-64. Professor Galanter analyzed this increase and found that $75 \%$ of it has come from just five categories of cases. In fact, the federal government alone has accounted for $50 \%$ of the increase in filings through a $413 \%$ rise in social security cases and a $6,683 \%$ rise in overpayment recovery cases. See Galanter, The Day After the Litigation Explosion, 46 MD. L. REv. 3, 16-17 \& table 2 (1986). Resolving these claims outside of the traditional court or administrative forums is problematic, given the disparity in resources between government and private parties. See Fiss, supra note 8, at 1076-78.

84 See Burger, Annual Report on the State of the Judiciary, 69 A.B.A. J. 442, 442-43 (1983) (the statutory and judicial creation of "new claims, entitlements, and causes of action" has contributed to heightened social expectations and a caseload increase). But see Galanter, supra note 83 , at 7 ( an increase in filings may be attributed to causes distinct from litigiousness, such as more recalcitrant negotiations by defendants, or the refusal of lawyers to get serious until a claim has been filed).

${ }^{85}$ See Paths to JuSTICE, supra note 4, at 7; see also Galanter, supra note 83, at 18-28 (sources of the increase have varied over time and include civil rights decisions and legislation broadening available actions and remedies); Marvell, Civil Caseloads: The Impact of the Economy and Trial Judgeship Increases, 69 JUDICATURE 153, 15356 (1985) (as economic activity increases, so do interactions among people and the number of legal claims between them).

${ }^{86}$ See PathS To JUSTICE, supra note 4, at 7 . One reason for the maintenance of this rate is that almost $95 \%$ of cases filed settle before trial. See Miller, supra note 2, at 4 n.7 (citing Administrative Office of the U.S. Courts, 1983 AnNual Report of THE Director 142 table 29); see also National Center for State Courts, State Court Caseload Statistics: Annual Report 1984173 (1986) (finding no evidence of a litigation explosion in a survey of almost one-half the states during 198184). 
caseloads as it is of increasingly complex civil litigation, ${ }^{\mathbf{8 7}}$ irrationally high legal fees, ${ }^{88}$ and the vexing delays that continue to mount despite increased emphasis by the judiciary on docket management. ${ }^{80}$ Still, these myths contain enough grains of truth and have invaded the popular imagination to such an extent ${ }^{90}$ that demands for alternative forums of dispute resolution have continued to intensify. The judicial system itself has been quick to embrace mandatory court-annexed arbitration ${ }^{91}$ as a means of resolving cases before trial.

One commentator has described this shift from court adjudication to $\mathrm{ADR}$ as the emergence of desirable, efficiency-producing competition. ${ }^{92}$ Before hailing the arbitration alternative as equal or superior to

${ }^{87}$ See Alschuler, supra note 80, at 1818 ("One suspects that some of those who have decried the litigation explosion have simply misspoken. Their ill-articulated complaint has not been about the volume of litigation, but rather the expanding reach of our substantive law."); American College of Trial Lawyers, Recommendations on $\mathrm{Ma-}$ jor Issues Affecting Complex Litigation, 90 F.R.D. 207, 209-10 (1981) (noting increases in complex cases in federal courts); Kirkham, Complex Civil Litigation - Have Good Intentions Gone Awry?, in The Pound Conference: Perspectives on JusTICE IN THE FUTURE 209-20 (1979) (discussing complex litigation primarily in the fields of antitrust, securities, and civil rights).

${ }^{88}$ See Ordinary Litigation, supra note 2, at 83, 121; Levin \& Colliers, supra note 4 , at 219-52.

${ }^{80}$ See Paths to Justice, supra note 4 , at $7-8$. The costs imposed by delays impair the administration of justice by forcing victims to accept inadequate settlements or relinquish their legal rights. See id. at 8 .

${ }_{90}$ See Galanter, supra note 83, at 3-5.

91 Court-annexed arbitration may be defined as the process requiring "that civil cases involving claims for damages between the ceiling for small claims and a higher amount (usually $\$ 10,000$ ) be submitted to arbitration by court-sponsored panels of attorneys. Either party has the right to appeal the judgment of the arbitration panel." Commercial Arbitration, supra note 9, § 3:25 (Practice Guide). Support for the process may be forthcoming from the legislature in the Court-Annexed Arbitration Act of 1987, H.R. 2127, 99th Cong., 2d Sess. 133 Cong. REc. H2132 (daily ed. April 22, 1987); see 1 Alternative Dispute Resolution Journal (BNA) at 42 (May 14, 1987). Some commentators have noted its increasing use throughout the country. See, e.g., Paths to Justice, supra note 4, at 18 (noting that "there is a growing popularity of court-annexed arbitration programs"); Edwards, supra note 7, at 673-75 (discussing the increasing popularity of court-annexed arbitration); Hensler, What We Know and Don't Know About Court-Administered Arbitration, 69 JuDiCATURE 270 (1986) (same); Levin, Court-Annexed Arbitration, 16 U. Mrch. J.L. REF. 537, 537 (1983) (same); Sarat, The Litigation Explosion, Access to Justice, and Court Reform: Examining the Critical Assumptions, 37 RuTGERs L. REv. 319, 335 (1985) ("[C]ourt reform efforts, especially efforts to promote ADR, need to be more focused and tailored to particular problem areas."); Snow \& Abramson, Alternative to Litigation: Court-Annexed Arbitration, 20 CAL. W.L. REv. 43, 43-57 (1983) (examining the court-annexed arbitration systems in Pennsylvania and California).

${ }^{82}$ See Brunet, supra note 8, at 7 ("Competition produces shifts towards efficiency and creates a healthy environment in which rival dispensers of dispute resolution seek to satisfy perceived demands."). But see Carrington, supra note 1, at 303-05 (arguing that cooperation, not competition, characterizes the relationship between private and public judicial services, since public institutions are "reluctant suppliers," not willing sellers, of such services). 
litigation, however, it would be wise to examine popular notions regarding the advantages of that forum and the frequently overlooked costs associated with its procedural shortcuts.

\section{Dispute Resolution: Means to an End, or the End Itself?}

The procedural structure of arbitration has been demonstrated using the AAA Commercial Arbitration Rules as the exemplar. ${ }^{93}$ Repose is the ultimate goal; the methods are strictly utilitarian. ${ }^{94}$ Since cost and delay are regarded as the twin evils of litigation, each rule of arbitration is directed toward offering the benefits of fast and inexpensive dispute resolution in a private forum by means of informal procedures intended to reduce the likelihood of subsequent judicial involvement. ${ }^{95}$

In most cases an arbitration begins quietly and intentionally remains so, even after the dispute is resolved. ${ }^{96}$ Such privacy is in marked contrast to cases that are litigated, because the function of court adjudication is not only to achieve repose between the parties, but also to enforce accepted norms of behavior and guide future behavior through the creation of new norms. ${ }^{97}$ However, the procedural devices associated with litigation, like discovery and the jury trial, cause frustration with the judicial process by fostering increased delay, expense, and unpredictability. ${ }^{98}$ Disputants are also discouraged by the combative nature of the adversary system, its procedural inflexibility, and the public aspects of adjudication. ${ }^{\text {99 }}$

${ }^{93}$ See supra notes 34-56 and accompanying text.

94 See Terrell, supra note 8, at 550-51.

95 Courts have long recognized the purpose of commercial arbitration and the concomitant substantive risk that the parties assume. See, e.g., American Almond Prods. Co. v. Consolidated Pecan Sales Co., 144 F.2d 448, 451 (2d Cir. 1944) (parties choosing arbitration "must content themselves with looser approximations to the enforcement of their rights than those that the law accords them," because arbitration is designed to avoid the procedural formalities that litigation employs to protect those rights).

${ }^{86}$ But see infra notes 153-69 and accompanying text (IBM-Fujitsu dispute).

97 See Brunet, supra note 8, at 16-17; Fuller, supra note 60, at 372-81; see also Fiss, The Supreme Court, 1978 Term-Foreword: The Forms of Justice, 93 HaRv. L. REv. 1, 2, 30-31 (1979) (comparing the private dispute resolution function of arbitration with the public, normative function of adjudication).

${ }^{98}$ See, e.g., American Law Institute, Study on "Paths to a 'Better Way': Litigation, Alternatives, and Accommodation," 34, 39-40 (Working Paper, July 1987) [hereinafter ALI Study] (the jury trial is a source of unpredictability in civil litigation); Atiyah, Lawyers and Rules: Some Anglo-American Comparisons, 37 Sw. L.J. 545, 555 (1983) (same); Solove, supra note 63, at 133-34 (noting that "the very nature of the adversary process" generates dissatisfaction with litigation); see also supra note 65 and accompanying text (criticizing discovery).

9o See Galanter, supra note 83, at 9, 38; Solove, supra note 63, at 134 . 


\section{a. Framing the Dispute}

Procedural differences with substantive consequences between arbitration and adjudication begin when a complaint is filed to initiate proceedings. Although most courts require only notice pleading from litigants, which is satisfied by a bare statement of the relevant facts and issues, ${ }^{100}$ a demand letter stating a party's intention to seek arbitration communicates even less information to the opposing party. ${ }^{101}$ Moreover, the lack of formal discovery means that a party cannot readily make up that factual shortfall. Accordingly, the capacity to formulate legal arguments is diminished:102 "Lawyers have little opportunity to know the extent of the issues or to limit them before the hearing." ${ }^{103} \mathrm{~A}$ harsh consequence is that the party with fewer resources is likely to be at a substantial disadvantage when the hearing date arrives. ${ }^{104}$ And as a rule, the inability to limit the scope of the issues contested at the hearing will waste time and perhaps confuse the arbitrator by clouding the most relevant points of the dispute.

\section{b. The Arbitrator}

The selection of the arbitrator has been called the lawyer's most

100 See, e.g., FED. R. Civ. P. 8(a)(2) (requiring "a short and plain statement of the claim").

101 See Bayer \& Abrahams, supra note 8, at 31.

102 See McDonald v. City of West Branch, 466 U.S. 284, 291 (1984) (citing Alexander v. Gardner-Denver Co., 415 U.S. 36, 57-58 (1974)) (the elimination of discovery has the effect of impairing factual development).

${ }_{103}$ Bayer \& Abrahams, supra note 8 , at 31.

${ }^{104}$ Antitrust cases are good examples of situations in which the parties have unequal bargaining power. See, e.g., Shell, A Better Approach to Contract Disputes, N.Y. Times, Sept. 13, 1987, at A2, col. 3 (The "lack of opportunity to review documents before a hearing in an antitrust case can be fatal to the plaintiff's chances for success."). The problem of unequal bargaining power, however, can arise in any commercial context. See Lieberman \& Henry, supra note 67, at 431 ("The party with the more meritorious claim might not prevail because he is too poor to amass the requisite evidence through the discovery process.").

When arbitration rules state that an arbitration clause is valid and enforceable except "upon such grounds as exist at law or in equity for the revocation of any contract," 9 U.S.C. § 2 (1982); N.J. STAT. ANN. § 2A:23A-2(a) (West 1987), this prohibition includes the inequality of bargaining power represented by an adhesion contract. The submission of a dispute to arbitration must be truly voluntary by both parties and not the result of a clause contained in a standard form printed contract presented to one party on a "take it or leave it" basis. See Commercial Arbitration, supra note 9, $\S 5: 04$. In reality, however, "the courts have not favored recognition of the 'adhesive" arbitration clause." Id.; see, e.g., Finkle \& Ross v. A.G. Becker Paribas, Inc., 622 F. Supp. 1505, 1512 (S.D.N.Y. 1985) (a standard form agreement between plaintiffs and broker providing for arbitration could not be considered an adhesion contract unless it is "not within the reasonable expectations of [the weaker] party" or, "when considered in its context, [it] is unduly oppressive, unconscionable or against public policy"). 
crucial decision, ${ }^{105}$ because she will determine what law, if any, is to apply to the facts of the case. Proponents of arbitration view this as one of its chief benefits, because the parties may choose arbitrators who are experts in a given field to decide matters. ${ }^{106}$ Thus, the parties benefit from the arbitrator's specialized knowledge of the trade or industry involved. ${ }^{107}$ Rather than wasting time educating a generalist judge or jury in the customs and practices of a particular field, the parties are able to concentrate their efforts upon resolving the dispute as speedily as possible.

Nevertheless, the use of experts presents potential problems. Arbitrators familiar with an industry's practices and the reputations of its members may bring with them not only specialized knowledge, but also the excess baggage of deeply ingrained beliefs and prejudices. ${ }^{108}$ Rather than presuming that it is always better to have a dispute resolved by someone familiar with the trade, prior knowledge must be balanced against the possible loss of impartiality. Not only might the generalist judge or jury bring a fresh approach to the problem, but the judicial system normally presides over a dispute without expertise in its underlying factual milieu. ${ }^{109}$ Perhaps the cost of educating the generalist is merely the price to be paid for impartiality.

\section{c. Discovery}

The absence of elaborate pretrial discovery may be arbitration's most efficient procedural innovation, since discovery is often a lightning rod for criticism of traditional civil litigation. ${ }^{110}$ Although parties may agree to exchange information, notwithstanding the relatively amicable nature of the proceedings, there is likely to be little cooperation. The FAA and some state arbitration statutes give arbitrators the power to subpoena documents and witnesses; ${ }^{\mathrm{in1}}$ but there is undoubtedly less

${ }^{105}$ See supra text accompanying note 44.

${ }^{106}$ See R. Coulson supra note 53, at 9; supra text accompanying note 63.

107 See Paths to Justice, supra note 4, at 13; Faure, supra note 2, at 206; Solove, supra note 63, at 137.

${ }^{108}$ See Bayer \& Abrahams, supra note 8, at 30.

109 Judge Edwards notes this fact, yet argues that judges are really legal specialists who should resolve disputes over issues of law. Conversely, when disputed issues are nonlegal, resolution may be handled through ADR. See Edwards, supra note 7, at 683-84.

110 See, e.g., Fletcher, supra note 22, at 454 (discussing the advantages of arbitration's limited discovery provisions and noting that "[t]he lack of the expensive elements of litigation is what makes arbitration so attractive"); supra note 65 and accompanying text.

111 See 9 U.S.C. $\$ 7$ (1982) (Federal Arbitration Act); UnIF. ARBITRATION ACT $\S \S 7($ a)-7(b), 7 U.L.A. 114 (1985); see also Brunet, supra note 8, at 33 ("[T]hese rules constitute only a brief and ambiguous venture into the positive law relating to 
prehearing development of the facts than there would have been in a court adjudication.

Pretrial discovery battles often serve to expose the worst aspects of the adversary system, ${ }^{112}$ and the limitations placed on such tactics in traditional ADR are reasonable in the routine cases involving repetitive facts and settled principles of law that make up the bulk of commercial arbitrations. ${ }^{113}$ Discovery abuses may well be an important factor underlying the "failing faith" in traditional adjudication, and perhaps rightfully so. ${ }^{114}$ Discovery is, nonetheless, crucial to the process of developing facts fairly, and only by knowing the facts can a decisionmaker possibly resolve a dispute accurately. ${ }^{115}$ Moreover, without adequate development of the facts, substantive law may not be correctly applied to the case. ${ }^{116}$ Disputants choosing arbitration must be willing, therefore, to forego the degree of accuracy that litigation provides through its provisions for regulated factfinding and reliance upon established legal principles. ${ }^{117}$ Similarly, "[t]o permit enforcement of the arbitration clause, [a] jurisdiction must be willing to permit the parties to contract not only out of dispute resolution in its courts, but also out of dispute resolution according to its laws." 118 Clearly, a private party may waive the right to have a claim based upon private rights resolved in a judicial forum. ${ }^{119}$ But these are not the troublesome cases; rather, what is dis-

discovery.").

112 See supra note 65 and accompanying text.

113 Discovery consumes time and money and can bog down disputants in trivial disagreements. See ALI Study, supra note 98, at 33. The informal nature of arbitration would be sacrificed if full discovery and sanctions for noncompliance were available. See PAths to Justice, supra note 4, at 13; Fletcher, supra note 22, at 454 . Moreover, without the threat of judicially-imposed penalties, a party probably would not engage in a meaningful exchange of information. See Brunet, supra note 8 , at 38 . Thus, discovery is unsuited to the nature of the arbitration forum. $C f$. Comment, Prehearing Procedures in Labor Arbitration: A Proposal for Reform, 43 U. PITT. L. REv. 1109, 1111 (1982) ("Traditionally, there has been no place for discovery in arbitration.").

114 See Resnik, supra note 8, at 540, 542.

115 See supra notes $102-03$ and accompanying text.

11 See Brunet, supra note 8 , at 31-39.

117 But see ALI Study, supra note 98, at 39-40 (jury trials render civil litigation unpredictable); Atiyah, supra note 98, at 555 (same).

118 Sterk, supra note 75, at 491.

119 See Commodity Futures Trading Comm'n v. Schor, 106 S. Ct. 3245, 3256 (1986) ("Article III's guarantee of an impartial and independent federal adjudication is subject to waiver, just as are other personal constitutional rights that dictate procedures by which civil and criminal matters must be tried."). Nevertheless, parties wishing to avoid the arbitration forum frequently dispute whether there was a waiver at all. In a case recently decided by the Seventh Circuit, a commodities brokerage firm argued that membership in a voluntary trade association did not constitute consent to the association's rule requiring arbitration of customer grievances, and thus there was no waiver of the constitutional right to a judicial forum. See Geldermann, Inc. v. Commodity 
turbing is the willingness of litigants, the legislature, and the courts to elevate the achievement of repose as an end in itself, without regard to the actual quality of a decision or the dispute resolution process.

\section{Resolution Without Reason: The Problem of Unsupported Awards}

By dispensing with written opinions, commercial arbitration's rulemakers affirm that the correct application of substantive law to a dispute is relatively unimportant among ADR's several goals. ${ }^{120}$ Presumably, it is equally unimportant to those who choose an alternative forum of dispute resolution. Indeed, the president of the AAA actively discourages arbitrators from issuing written decisions, because doing so would facilitate an attack on the award by the losing party and subsequent judicial review. ${ }^{\mathbf{1 2 1}}$ The upshot of written arbitration opinions would be to undercut expeditious dispute resolution by impairing the finality of the arbitrator's decision. ${ }^{\mathbf{1 2 2}}$ Because this result is inconsistent with the concept of arbitration, which intends to provide an alternative to the formalities, the delay, the expense, and the vexation of ordinary litigation, no written opinion is required.

Without a full development of the facts by the parties, and perhaps possessing only a nodding acquaintance with relevant substantive law, it may be unclear how the arbitrator actually arrives at her decision and the remedy to impose. The absence of a written opinion justifying the resolution clouds the reasoning process even further. Although ADR's proponents criticize litigation as capricious, ${ }^{123}$ a lack of predictability is perhaps arbitration's most irksome characteristic. ${ }^{124}$ This can

Futures Trading Comm'n, 836 F.2d 310, 318 (7th Cir. 1987). The court denied this claim by relying on the rejection of similar challenges to the National Association of Securities Dealers' arbitration rules in Patten Sec. Corp. v. Diamond Greyhound \& Genetics, Inc., 819 F.2d 400, 404 (3d Cir. 1987). See Geldermann, 836 F.2d at 31819.

The Geldermann court did recognize that a waiver may be ineffective when separation of powers principles are implicated. See id. at 321. The court, however, held that the arbitration rule in question did not "threaten[] the structural integrity of the courts or the separation of power between the branches of the federal government." Id. at 323.

120 See Patrs to Justice, supra note 4 , at $12-13$ \& table 4.

121 See $\mathrm{R}$. Coulson, supra note 53, at 29.

${ }^{122}$ See id. at 25. But see Lyons, Arbitration: The Slower, More Expensive Alternative?, 11 AM. LAw., Jan.-Feb. 1985, at 107, 109 (in some cases, court battles over the award make arbitration as expensive and time-consuming as litigation).

${ }^{123}$ See, e.g., 1 Alternative Dispute Resolution Rep. (BNA), at 300 (Nov. 26, 1987) (companies choose ADR to avoid the "capriciousness" of the court system); $c f$. note 98 and accompanying text (noting the unpredictability of jury trials).

124 See, e.g., Bush, supra note 78, at 988-89 \& n.203 (the failure of arbitration to apply rules correctly and communicate them to other parties makes it less efficient than 
result in similarly situated parties, before the same or a different arbitrator, having their disputes resolved inconsistently based upon the decisionmaker's own notions of fairness. The principle of stare decisis, which would conflict with the expediency of arbitration by requiring a known and preserved body of law from which precedent could be applied, is reduced to irrelevance. ${ }^{125}$

The most disturbing characteristic of arbitration decisionmaking is revealed by evidence that arbitrators frequently compromise on decisions rather than resolve the underlying dispute between the parties. ${ }^{126}$ Ironically, without a written opinion, such a result is almost predictable. Considering that the parties normally select the arbitrators, and that the arbitrators only derive income when they work, it does not require much imagination to realize that an arbitrator has a strong interest in keeping everyone as happy as possible. ${ }^{127}$ The best method of accomplishing this is compromise; thus, in the typical arbitration, neither side is as likely to prevail "as in the "winner-take-all" style of adjudication. ${ }^{128}$ No rights are vindicated; rather, the controversy is swept under a rug and the parties are left reasonably-though perhaps only temporarily-content. That such contentment exacts a price from the rest of society is the subject of the next Section of this Comment.

\section{B. The Jurisprudential Functions of Litigation}

Compromise decisions may be harmless in the routine high-vol-

adjudication in some circumstances); Lasersohn, supra note $8, \S 11$, at 28 , col. 2 (a lack of predictability is one of the primary complaints with arbitration).

${ }_{125}$ Stare decisis is the judicial doctrine requiring a court to apply settled principles of law to a certain state of facts, thereby adhering to precedent. See BLACK's LAW DictionaRY 1261 (5th ed. 1979). ADR, which has no requirement that decisions adhere to established principles, or any means of communicating the basis of a decision to future disputants, inevitably renders this doctrine meaningless. See Terrell, supra note 8 , at 543-45.

${ }^{126}$ See, e.g., Federal Commerce \& Navigation Co. v. Kanematsu-Gosho, Ltd., 457 F.2d 387, 390 (2d Cir. 1972) (acknowledging that arbitrators have the power to render compromise decisions according to their own sense of fairness); Brunet, supra note 8 , at 4 (compromise is the ADR norm and the basis of its claim of qualitative superiority); see also ForUM COMMITTEE ON THE CONSTRUCTION INDUSTRY, LITIgation Section, American Bar Association, Statistical Survey 4 [hereinafter STATISTICAL SURVEY] (forty-six percent of attorneys responding agreed that arbitrators sometimes "unjustifiably render a compromise decision").

${ }^{127}$ See Bush, supra note 78 , at 989 \& n.204 (arguing that arbitrators must vary their rules of decision to avoid rejection by parties otherwise able to foresee defeat). On the other hand, the AAA contends that its arbitrators frequently volunteer their time or work for a nominal fee. In complicated cases, however, payment will likely be required. See Coulson, supra note 38, at 681.

${ }^{128}$ Proponents of ADR view compromise as a qualitative benefit. See, e.g., Lieberman \& Henry, supra note 67, at 429 (freedom from legal principles allows creative remedies that benefit both parties). 
ume, low-stakes disputes that arbitration was designed to resolve quickly and inexpensively. ${ }^{129}$ But from a jurisprudential standpoint, the consequent absence of identifiable decisional norms and the subjugation of individual rights in favor of achieving repose may threaten the proper administration of justice in both present and future cases. ${ }^{130}$ One of ADR's foremost critics, Professor Owen Fiss, argues that "[a]djudication is more likely to do justice than . . . arbitration . . . or any other contrivance of ADR, precisely because it vests the power of the state in officials who act as trustees for the public, who are highly visible, and who are committed to reason."

Arbitration's lack of procedural safeguards is less bothersome in the legally routine and factually repetitive cases that frequently develop during the term of a commercial contract. ${ }^{132}$ In recent years, though, arbitration has been called upon to resolve claims based upon important public policies. ${ }^{133}$ The American legal system depends upon the private enforcement of public as well as private rights, but a problem arises when issues of public law are hidden within seemingly private disputes. ${ }^{134}$ Routinely resolving private disputes through arbitration or other forms of ADR may cause important public rights issues to be settled without much concern for the quality of the dispute resolution process. ${ }^{135}$

${ }^{129}$ See Bush, supra note 78, at 990-91 (arbitration is more appropriate than adjudication in "routine cases involving purely factual issues," but not in cases involving "numerous or important questions of principle").

${ }_{130}$ Although parties purportedly waive their rights by consenting to arbitration, the waiver may have been neither voluntary nor permissible. See supra note 119 and accompanying text.

131 Fiss, Out of Eden, 94 Yale L.J. 1669, 1673 (1985).

132 Litigation has developed from disputes over late deliveries, inferior merchandise, or nonpayment. See, e.g., Mitsubishi Motors Corp. v. Soler Chrysler-Plymouth, 723 F.2d 155, 155 (1st Cir. 1983) (arbitration concerning nonpayment of fees), modified, 473 U.S. 614 (1985); C. Itoh \& Co. v. Jordan Int'] Co., 552 F.2d 1228, 1230 (7th Gir. 1977) (arbitration concerning late delivery of alledgedly defective merchandise); Schneider, Inc. v. Research Cottrell, Inc., 474 F. Supp. 1179, 1180 (W.D. Pa. 1979) (arbitration concerning contract interpretation and alleged fraud).

${ }_{133}$ See, e.g., Shearson/American Express, Inc. v. McMahon, 107 S. Ct. 2332, 2343-44 (1987) (disputes under RICO and $\S 10(\mathrm{~b})$ of the Securities and Exchange Act of 1934-statutes involving crucial public policies-are arbitrable).

134 See Edwards, supra note 7, at 671 (issues of public law "include constitutional issues, issues surrounding existing government regulation, and issues of great public concern . . . . [that] might include, for example, the development of a legal standard of strict liability in products liability cases"); supra note 75 and accompanying text.

135 The failure of ADR's proponents to consider what is lost by diverting cases away from litigation has created what Professor Brunet calls the "Second Wave" of ADR analysis. See Brunet, supra note 8, at 4-6. While acknowledging the negative aspects of traditional court adjudication, this group of commentators emphasizes instead the advantages of the judicial system as a means of dispute resolution and the importance of its role in preserving the structure of society. Given the broad policies favoring 


\section{Beyond Fees: The Intangible Costs of Arbitration}

The "adjudicatory mode" offers some theory of its own limits, distinguishing between, permissible and impermissible adjudication. ${ }^{136}$ Arbitration, by contrast, is legitimated only by its procedural advantages. ${ }^{137}$ Without safeguards, arbitration lacks an internal structure akin to the common law to impart similar consistency and value to decisions. ${ }^{138}$ The common law principle of stare decisis, for example, employs precedent established through adjudication in order to create that structure. Arbitration decisions, on the other hand, are specific to one dispute and have no lasting precedential value. ${ }^{139}$ Arbitration, therefore, lacks the legal rules developed incrementally through relevant cases that, in traditional adjudication, legitimize past decisions and render future decisions more predictable. ${ }^{140}$ Contracting parties can better plan their behavior according to clear and consistent legal rules as long as the parties are aware of the decisions and understand the rationale behind the ruling. ${ }^{141}$

If enough cases are diverted to arbitration, this rulemaking power exercised by the courts may be hindered. Besides functioning to resolve disputes, which arbitration also accomplishes quite well, litigation facilitates the development of a body of law and related rules that "serve to guide society."142 The creative ad hoc decisions characteristic of arbitration threaten to impair the role of legal norms in broadly guiding the actions of society, so that any major shift from adjudication to arbitration or other modes of ADR presents questions of "significant jurisprudential impact."143 Compromise decisions play a large part in undermining substantive norms; indeed, "[t]he preference for compromise

arbitration, these "Second Wave" concerns have become more pressing, and the pursuit of purely procedural goals more troubling. Elevating the value of efficient justice, they argue, may slight substantive process and substantive justice. See id.; Menkel-Meadow, supra note 62 , at $489-90$.

${ }^{136}$ See Resnik, supra note 8, at 546.

${ }^{137}$ See id.

${ }^{138}$ See Brunet, supra note 8, at 19-20; Terrell, supra note 8, at 544.

139 See supra notes $124-25$ and accompanying text.

140 See Brunet, supra note 8 , at 7; Bush, supra note 78 , at 989 ; Resnik, supra note 8 , at 546 .

${ }^{141}$ See Brunet, supra note 8, at 54 ("[S]ubstantive laws 'guide' or 'order' society generally and, in particular, affect large numbers of citizens who attempt to comply with positive law. . . . Law's guidance function requires clear, unambiguous norms to work effectively."); see also Terrell, supra note 8, at 545 ("The two basic functions of general rules in a legal system are to offer guidance concerning potential future action and to serve as standards for the assessment of past actions.").

142 Brunet, supra note 8 , at 5 .

143 Id. at 7. 
erodes the very function of substantive law."144

In the context of considering private litigants as private attorneys general charged with enforcing public law and its underlying policies, ${ }^{145}$ the debilitating effect of compromise decisions becomes clearer. A statute is a legislative policy choice, but without subsequent judicial development through the public resolution of disputes, that policy will remain stagnant, or perhaps wither entirely. The ambiguous statutory language that frequently results from legislative compromise remains with the understanding that the courts will supply an interpretation. Even if initial principles are established through adjudication, permitting the arbitration of an entire category of claims restricts further evolution in that area of the law by reducing the number and variety of claims presented to the courts. This kind of substantive inefficiency, disregarded by litigation's critics, must be balanced against the more mundane efficiencies of time and cost that arbitration purports to offer.

Without substantive norms, dispute resolution remains undisciplined and of no use to anyone but the disputants. Of course, an arbitrator is probably aware of the substantive law relevant to a dispute, ${ }^{\mathbf{1 4 6}}$ and may choose to apply it as best she can. However, similarly situated parties derive no benefit when there is no reasoned opinion to explain her decisionmaking process. Thus, although arbitration represents procedural reform, the practice of hearing every claim as if it were presented tabula rasa would seem to be an inefficient application of those reforms. Moreover, it allows procedural reform to "swallow substance." 147

The suspect quality of arbitrated decisions should be considered by a reviewing court when the accuracy and basis of a decision is important. ${ }^{148}$ For example, one commentator has noted the troublesome practice of according preclusive effects to an arbitrated decision in a subsequent judicial proceeding. ${ }^{\mathbf{1 4 9}}$ Given the informal nature of most

144 Id. at 16.

145 See id. at 20-21.

${ }_{146}$ This concept is referred to as "bargaining in the shadow of the law." Id. at 27-28; see also R. Coulson, supra note 53, at 31 (stating that an arbitrator is bound to listen to the parties' legal arguments and should consider them when rendering a decision). The pervasiveness of substantive law implies that legal principles influence ADR proceedings, although to an uncertain extent. See Brunet, supra note 8, at 27-28.

${ }_{147}$ Brunet, supra note 8 , at 31 .

${ }_{148}$ See Stroh Container Co. v. Delphi Indus., Inc., 783 F.2d 743, 751 n.12 (8th Cir.) (" $[W]$ here arbitration is contemplated the courts are not equipped to provide the same judicial review given to structured judgments defined by procedural rules and legal principles. Parties should be aware that they get what they bargained for and that arbitration is far different from adjudication."), cert. denied, 476 U.S. 1141 (1986).

${ }_{149}$ See Shell, Res Judicata and Collateral Estoppel Effects of Commercial Arbitration, 35 UCLA L. REV. 623, 661 (1988)). 
arbitrations, and the uncertain basis of the arbitrator's decision, carelessly awarding the decision res judicata and collateral estoppel effects seems unfair. ${ }^{150}$ Moreover, because the scope of an arbitration is governed by the contract that provides for it, carelessly according the decision preclusive effects may give the prevailing party more than the parties intended when they entered into the agreement. ${ }^{151}$ Motivated in part by the perceived "litigation explosion," however, courts have freely applied preclusion doctrines to arbitration without weighing the differences in procedural regularity or the intent of the parties. ${ }^{152}$

\section{Case in Point: The IBM-Fujitsu Arbitration Decision}

A major case arbitrated under the auspices of the AAA brings to life many of the positive and negative characteristics of arbitration as compared to litigation, particularly the assertion that "ADR focuses on the ending of a dispute and the creation of a framework for avoiding future disputes."153 In that case, IBM, the largest computer manufacturer in the world, and Fujitsu, the largest Japanese computer manufacturer, resolved a long-standing battle over Fujitsu's development of IBM-compatible operating system software. ${ }^{154}$ Such development required access to information that IBM alone possessed, and IBM demanded compensation for the privilege of using that information. Since copyright law in this particular area remains unsettled, the parties could not agree whether such information was protected by law from unauthorized use. ${ }^{185}$ An earlier agreement between the parties requiring Fujitsu to make substantial semiannual payments for obtained information had quickly collapsed under the weight of undefined terms. ${ }^{156}$ Fujitsu had been selling the IBM-compatible software to its customers for a long time, so that large amounts of money and the good

160 See id. at $657-60$.
${ }^{161}$ See id. at 662.
${ }^{162}$ See id. at 661.
${ }^{163}$ Brunet, supra note 8, at 14.
${ }_{154}$ See IBM v. Fujitsu Ltd., No. 13T-117-0636-85 (AAA Commercial Arbitration Tribunal Sept. 15, 1987) (Jones \& Mnookin, Arbs). "An operating system is an organized collection of software used to assist and in part control the operations of a computer. Operating systems generally manage the internal functions of the computer and facilitate the use of applications software." Id. at 3-4. The operating system programs involved in this arbitration were large and complex, representing an investment of hundreds of millions of dollars. See id. at 4.

${ }^{100}$ See id. at 5-6, 29 n.8.

${ }^{156}$ See id. at 6-8. For example, Fujitsu promised to respect IBM's intellectual property rights, but the scope of those rights and the applicable law were not defined. See id. at 8. Moreover, neither the type of information obtainable by Fujitsu nor the price to be charged for its use was specified. See id. 
will of many Fujitsu customers were at stake. ${ }^{167}$

The arbitrators' remedy was so unique, and the stakes so high, that the AAA placed full-page advertisements announcing the decision in The Wall Street Journal and The New York Times. ${ }^{158}$ The arbitrators' order resolved all past claims between the two parties and established a structure to inhibit future disputes. ${ }^{159}$ The forward-looking agreement entailed the construction of a "Secured Facility" in which Fujitsu would be allowed to examine information possessed by IBM necessary to the continued production of compatible software. In return, IBM received a lump sum payment for past, present, and future use of its materials and for the substantial investment involved in their development-a de facto license obtained by Fujitsu. ${ }^{160}$ IBM was given the right to examine Fujitsu data, but does not expect to exercise it. A neutral third party, supervised by the arbitrators, will strictly control this exchange process for the duration of the agreement-a period of between five and ten years. ${ }^{\mathbf{1 6 1}}$ Information properly obtained by either side at the Secured Facility will be immune from claims of copyright infringement. ${ }^{162}$

The nature of this remedy underscores both the flexibility available to disputants choosing arbitration and the benefit of having experts serve as arbitrators. One of the arbitrators is a retired computer expert, the other a law professor specializing in the study of alternative forms of dispute resolution. ${ }^{163}$ This expertise undoutedly assisted them in understanding the facts and fashioning an appropriate remedy. Moreover, the controversy was resolved in less than two years-substantially less time than might have been expected had the case been formally adjudicated. ${ }^{164}$ Finally, the legal fees, while no doubt large, were most likely smaller than they would have been had the dispute been litigated.

The order also achieved a consistent outcome between the parties, a substantial benefit given the size of the stakes involved. ${ }^{165}$ IBM will have knowledge of Fujitsu's software development before the product

167 See id. at 5-6.

168 See N.Y. Times, Sept. 16, 1987, at D17; Wall St. J., Sept. 16, 1987, at 21.

158 See $I B M$, at 1-3.

160 See id. at $20-28$.

161 See id. at 21.

162 See id. at 21-22.

${ }^{163}$ See AAA, Arbitrators Resolve IBM-Fujitsu Software Dispute, Press Release, at 1 (Sept. 15, 1987) (on file with the University of Pennsylvania Law Review).

${ }_{164}$ In 1984 , the median time to disposition for litigated cases in the federal district courts alone was nineteen months. See Galanter, supra note 83 , at 26 table 4 .

165 The arbitration decision did not reveal the amount of money Fujitsu paid, but the economic might of the parties indicates that the sums at stake were probably very large. See Arbitrator J. Jones, Statement at Press Conference 3 (Sept. 15, 1987) (on file with the University of Pennsylvania Law Review). 
hits the market, and Fujitsu knows that IBM cannot bring any claims against it related to material properly acquired at the Secured Facility. Perhaps most important, a stable, working relationship was preserved between two powerful multinational corporations to both of their benefits and the benefit of their many customers. As one of the arbitrators noted, "It is because both companies prefer to devote resources to marketplace competition rather than copyright and contract battles that this order is possible."168 While it is the rare company that would prefer litigation to business as usual, the spirit of his assertion is accurate: economic resources were put to a more efficient use.

Lost, however, was an opportunity for the judicial system to further the substantive development in this particular area. The facts and issues involved in this controversy were rich; ${ }^{\mathbf{1 6 7}}$ the uncertainty of applicable copyright law would have sharpened the controversy. Although the parties were most concerned with the issue of compensation, the ultimate resolution of this concern was dependent upon whether or not IBM's intellectual property rights had been violated, an issue deemed too costly and time-consuming to resolve. ${ }^{168}$

Rather than having been permitted the opportunity to settle an area of intellectual property law, society has been left to interpret the meaning and relevance of a compromise decision. Computers pervade society, and their influence can only expand. If copyright law is to apply at all, courts should have an opportunity to direct the development of that law in relation to the computer industry. Although private parties are not obligated to litigate their disputes, IBM and Fujitsu had the resources to obtain the best legal talent available and withstand the financial burden of adjudication. ${ }^{169}$

${ }^{166}$ Arbitrator R. Mnookin, Statement at Press Conference 4 (Sept. 15, 1987) [hereinafter Mnookin Statement] (on file with the University of Pennsylvania Law Review).

${ }_{167}$ See id. at 12 ("The Panel has received an astounding volume of letters, memoranda, documents and exhibits on numerous points and issues.").

${ }_{188} \mathrm{See} i d$. at 3 . As Fujitsu's lead counsel explained with unintended irony, "Existing copyright doctrine is not particularly well-suited, in our view, to resolution of computer software development issues. We believe alternative methods of dispute resolution, such as those employed in this arbitration, are more likely to produce rational answers to these issues than conventional litigation procedures." R. Raven, Statement in Press Conference Press Kit Concerning the IBM-Fujitsu Dispute 1 (Sept. 15, 1987) (on file with the University of Pennsylvania Law Review).

168 The argument that private parties should not be expected to bear the additional costs of litigation would be persuasive if it were valid. However, the assumption that private parties usually spend more money in court is simply not true. See Kritzer \& Anderson, The Arbitration Alternative: A Comparative Analysis of Case Processing Time, Disposition Mode, and Cost in the American Arbitration Association and the Courts, 8 Just. Sys. J. 6, 14-19 (1983). Complex cases cost more in both forums, and publicly-funded courts actually cost less to use than the entirely fee-supported arbitra- 
The IBM-Fujitsu arbitration exposes the difficult questions generated by the growth of the ADR movement. It illustrates the costs incurred when issues on the cutting edge of the law are diverted to the various $A D R$ systems: legal rules are denied a chance to evolve, to the detriment of the legal process. In this case, because the arbitrators were free to ignore copyright doctrine, an opportunity was squandered to refine that doctrine further.

Resolving this dispute in an alternative forum saved time and money and achieved repose between the parties. In addition, similarly situated parties on their own may adopt the creative remedy produced in this dispute, thereby eliminating the need for courts to revisit the factual and legal tangle that characterizes computer industry disputes. The failure to develop a new principle of intellectual property law, however, imposes broader costs upon society. The arbitrators' remedy in this case is temporary and applicable only to the two parties involved. As a result, other members of the industry have been denied the guidance that a legal rule would impart upon their dealings with one another, so that these companies may be forced to bear the costs of an adverse decision either in future court cases or arbitration decisions. Moreover, an eventual resolution of the larger legal issues was merely postponed, perhaps left to smaller and less financially capable players to settle in court. Given these factors, many of the resources employed to arrive at the IBM-Fujitsu decision may have been wasted, from society's point of view.

Theoretically, judicial resolution would have governed the dealings of all similarly situated parties and achieved repose of the issues, at least temporarily. Frustration with the expense and delay of traditional litigation, however, encouraged the parties to pursue resolution in an alternative forum. Although the parties are satisfied with the resolution of their dispute, and finite judicial resources were conserved, the arbitration imposed substantive costs upon the parties and society. The

tion forum. See id. at 17. No additional burden is imposed on private litigants if use of the courts is encouraged for particular disputes. Arbitration may be faster than adjudication, however, even with any subsequent appeals from the arbitrated award. See id. at 11-14, 18. Arguably, streamlined procedures could remove any disparity caused by delayed access to the courts.

Implicit in the result of the IBM-Fujitsu arbitration is the fact that what is best for private litigants is not necessarily best for society. The norms that society may derive from formal adjudication require the parties involved to endure "weighty opportunity costs." Brunet, supra note 8 , at 51 . Consequently, "the demand for judicially imposed substantive norm enforcement barely exists." Id. Thus, society cannot rely upon private parties to enter the public forum when an issue needs to be litigated if a satisfactory resolution of the dispute can be achieved in an alternative forum such as arbitration. In order to ensure that norms are created and enforced, the use of courts should be encouraged for particular types of cases. 
challenge remains to ameliorate these substantive costs as much as possible without sacrificing the procedural benefits of ADR generally, and arbitration in particular. The next Part of this Comment will explore the balance that must be struck between substantive norms and expeditious procedures.

\section{The New Jersey Alternative Procedure For Dispute RESOLUTION ACT}

\section{A. The Goal of Reform}

The goal of ADR's reformers is to protect the quality of justice dispensed in alternative forums such as arbitration. ${ }^{170}$ This Comment emphasizes the need for reform in commercial arbitration procedures so that statutory policies ${ }^{171}$ will be adequately enforced and substantive law ${ }^{172}$ correctly applied. ${ }^{173}$ The NJADR Act provides the precise system of checks and balances suggested by this critique of arbitration, including streamlined procedures necessary for efficient repose and substantive safeguards necessary to protect public rights. ${ }^{174}$

170 See supra notes $72-78$ and accompanying text.

171 See supra notes 74-75 and accompanying text; supra notes 133-35 and accompanying text.

${ }^{172}$ See supra notes $120-28$ and accompanying text.

173 See, e.g., Brunet, supra note 8 , at 54-55 ("[P]rocedural innovation is needed to ensure that $A D R$, like any procedural reform, remains subordinate to substantive law."); Edwards, supra note 7, at 676-78 (arbitrators should be restricted to private disputes in order to protect established public rights); Shell, supra note 104, $\S 3$, at 2 , col. 3 (arguing that if antitrust disputes are to be arbitrated, procedures must be modified to protect the policies underlying antitrust laws).

${ }^{174}$ See infra notes $185-214$ and accompanying text. The development of the NJADR Act was precipitated by the unusual state of arbitration law in New Jersey after two decisions, Grover v. Universal Underwriters Ins. Co., 80 N.J. 221, 403 A.2d 448 (1979), and Communications Workers of Am. v. Monmouth County Bd. of Social Servs., 96 N.J. 442, 476 A.2d 777 (1984), in which the state supreme court held that a mistake of law by an arbitrator was grounds for reversing the award on review. See Grover, 80 N.J. at 230-31, 403 A.2d at 451; Communications Workers, 96 N.J. at 453,476 A.2d at 781 . This holding was startling because it contradicted the weight of judicial opinion, in New Jersey and elsewhere, that had normally upheld arbitration awards even if they were intentionally decided contrary to applicable law. See Grover, 80 N.J. at 234-36, 403 A.2d at 454-56 (Pashman, J., dissenting); Carpenter v. Bloomer, 54 N.J. Super. 157, 168, 148 A.2d 497, 503 (App. Div. 1959) (an award will not be set aside because a court would have construed law differently); Collingswood Hosiery Mills, Inc. v. American Fed'n of Hosiery Workers, 31 N.J. Super. 466, 471, 107 A.2d 43, 45 (App. Div. 1954) (an arbitrator may decide "according to his own concept as to what is just and right"); see also La Vale Plaza, Inc. v. R.S. Noonan, Inc., 378 F.2d 569, 572 (3d Cir. 1967) (an arbitrator's "decision will not be disturbed for a mistake of fact or law"); Sprinzen v. Nomberg, 46 N.Y.2d 623, 629, 389 N.E.2d 456, 458-59, 415 N.Y.S.2d 974, 977 (1979) ("an arbitrator's award will not be vacated for errors of law and fact"); Lentine v. Fundaro, 29 N.Y.2d 382, 385, 278 N.E.2d 633, 635,328 N.Y.S.2d 418, 421 (1972) ("arbitrators are not bound by principles of sub- 
If the safeguards accompanying court adjudication are added to the arbitration structure, however, "have we done anything other than reinvent the wheel?"175 If the primary motivation for choosing commercial arbitration is streamlined procedures, which have the concomitant benefits of speed and low cost, would not the addition of an elaborate judicial-type structure be self-defeating? If commercial arbitration becomes a replica of traditional litigation, then its attractiveness as a form of ADR will disappear, and its value as an alternative to litigation will be negated. As discussed below, however, the NJADR Act has balanced procedural reform with certain limiting principles, a compromise that may have successfully synthesized the best of both processes of dispute resolution. ${ }^{178}$

stantive law").

As a result of this shift in the standard of review, and the fact that arbitrators rarely explain the reasons underlying an award, arbitration in New Jersey became more than ever a beginning to litigation rather than an end. Cf. Grover, 80 N.J. at 237, 403 A.2d at 456 (Pashman, J., dissenting) (arguing that the majority's review of an arbitration proceeding was setting a precedent that would allow parties a hearing de novo, thus making arbitration a mere springboard to litigation). A disappointed party would almost always have an incentive to attack the award, because without an opinion setting forth the basis of the decision, it is difficult to determine the law that the arbitrator applied.

The New Jersey Supreme Court further confused this issue when it held in Heffner v. Jacobson, 100 N.J. 550, 498 A.2d 766 (1985), that common law rules were applicable in statutory arbitration if the contract's arbitration clause was silent as to whether the common law or the arbitration statute applied to the underlying dispute between the parties. See id. at 554-55, 498 A.2d at 768. The coexistence of common law and statutory arbitration rules is common, see Commercial Arbitration, supra note $9, \S 3: 02$, and other jurisdictions have reached the same conclusion on the issue, see Heffner, 100 N.J. at 554-55, 498 A.2d at 768; see also La Vale Plaza, 378 F.2d at 571-72 (indicating that under the Pennsylvania Arbitration Act of 1927, the parties must specifically refer to the Act in order to have its provisions, and not the common law, apply); A.J. Curtis \& Co. v. D.W. Falls, Inc., 305 F.2d 811, 813 (3d Cir. 1962) (same); Jones v. John A. Johnson \& Sons, Inc., 129 N.Y.S.2d 479, 481 (1954) (same). Heffner and Grover render the result under judicial review entirely dependent upon the standard of review applied, which in turn depends upon the rules under which the case has been arbitrated. See Lasersohn, supra note $8, \S 11$, at 28 , col. 2. Arbitration awards under the state arbitration act, N.J. STAT. ANN. \$\& 2A:24-1-24-11 (West 1987), must be in accord with applicable law after Grover, but common law arbitration awards are still reviewed under the familiar "manifest disregard of the law" standard.

The additional unpredictability introduced into commercial arbitration by these decisions gave ADR reformers in New Jersey the incentive to devise a new structure for the nonjudicial resolution of commercial disputes. See Lasersohn, supra note 8 , $\S 11$, at 28, cols. 1-2; June Sturtz Statement, supra note 16, at 1-2.

${ }_{175}$ Resnik, supra note 8, at 554.

${ }^{178}$ Similar to arbitration in many respects, the procedure established by the NJADR Act is meant to compete with existing forms of ADR rather than replace them outright. The procedure is entirely voluntary and must be designated by the parties as the source of rules governing dispute resolution. See N.J. STAT. ANN. § 2A:23A-2(a) (West 1987). Still, its proponents would like to see it supplant commercial arbitration. See Naiman, supra note 39, at 3, col. 4 (reporting that NJADR Act state assembly sponsor Robert J. Martin stated, "Businessmen have no confidence in arbitration. The 
The heart of the Act is the provision requiring the umpires, the system's decisionmakers, to resolve disputes according to substantive law. ${ }^{177}$ This requirement follows inevitably from the body of New Jersey case law holding arbitrators to an identical standard of accurate decisionmaking as judges. ${ }^{178}$ Additionally, other procedural innovations were needed to facilitate the rendering of legally correct decisions. Thus, rather than focusing purely on achieving the rapid repose that arbitration promises, the NJADR Act seeks to enhance the quality of the result reached. ${ }^{179}$ Gritics dismiss the Act as an unnecessary hybrid of arbitration and litigation-a reinvention of the wheel. ${ }^{180}$ In fact, the NJADR Act is a careful blend of existing modes, offering procedural convenience and substantive protection, ${ }^{\mathbf{1 8 1}}$ the goals of which are to confer predictability upon ADR decisionmaking and facilitate review of those decisions in the courts. ${ }^{182}$

\section{B. The Act's Mechanism}

1. Jurisdiction

As with statutory arbitration, the parties must voluntarily invoke the jurisdiction of the NJADR Act; they must either specify in the text of their agreement that any disputes arising under the contract will be resolved under the Act, or agree after the dispute has arisen to submit their claims to this process for resolution. ${ }^{\mathbf{1 8 3}}$

Voluntary election underscores the fact that conventional arbitration is well suited to resolution of particular types of disputes, and that to force these into the NJADR Act procedures is inefficient. For example, if preservation of a business relationship is most important to the parties, as it was in the IBM-Fujitsu arbitration, efficiency will be the primary factor in choosing a mode of dispute resolution. Thus, although one could argue that the need for NJADR Act procedures in any context could be obviated by amending the FAA or state arbitra-

problem is that it is often the start of litigation ...."); October Sturtz Statement, supra note 6 , at $1-3$.

177 See N.J. Stat. ANN. § 2A:23A-12(e) (West 1987).

178 See supra note 174.

179 See Lasersohn, supra note 8, § 11 at 28, col. 2; see also supra notes 120-28 and accompanying text; 137-52 and accompanying text (the quality of ADR depends upon accurate factfinding and correct application of substantive law).

180 See, e.g., Naiman, supra note 39, at 3, col. 4 (statement of Richard Naimark, regional AAA director).

${ }^{181}$ See infra notes $184-214$ and accompanying text.

182 See N.J. StAT. ANN. § 2A:23A-12 at 47 (West 1987) (Draftsman's Legislative History).

${ }^{183}$ See id. § 2A:23A-2(a). 
tion statutes, such additional procedures are superfluous in the average commercial dispute and would only prove to be burdensome.

On the other hand, if the parties believe that the dispute is very important, they may want it decided according to law, with detailed factual findings and a written opinion. Perhaps, as in the context of securities arbitration, one party fears that its inferior bargaining power will compromise its rights in a forum in which the opposing party exerts substantial influence. Regardless, establishing alternatives allows the parties to designate the best forum for the resolution of a particular dispute.

Private parties, however, cannot be expected, to safeguard institutional interests and legislative policies when choosing a method of dispute resolution. This problem has been further exacerbated by the Supreme Court's strong encouragement of arbitration in recent years. Perhaps the Court would not be as enthusiastic about the arbitration of certain categories of disputes if an alternative were available that could provide some degree of substantive protection without taxing judicial resources. In this respect, the NJADR Act procedures are a convenient compromise: if a party challenged an agreement to arbitrate and important rights were implicated in the dispute, the courts could have an alternative to arbitration. Of course, a court could not arbitrarily void an arbitration agreement between the parties, but it could conceivably require more formalized procedures in the name of public policy.

Once jurisdiction has been established, differences begin to appear between NJADR Act procedures and those of AAA commercial arbitration. In demanding the resolution of the dispute, a party must provide written notice setting forth all claims, defenses, and the relief sought. ${ }^{184}$ The notice given an opposing party is thus sufficiently informative to permit a fair development of both sides of the argument; at a minimum, the opposing party knows its position relative to the complainant before further communication is undertaken.

\section{Umpires}

The process of choosing an umpire, as the judges are called under the NJADR Act, differs from the selection of arbitrators under AAA rules. Only one umpire is appointed according to a pre-established procedure set forth in the contract, which either designates the umpire or

${ }^{184}$ See $i d . \S 2 \mathrm{~A}: 23 \mathrm{~A}-4$ (a). In a survey of attorneys experienced in arbitration of construction industry disputes, $79 \%$ wanted the complaining party to be compelled to file a detailed statement of the claim prior to the proceeding. See STAtistical Survey, supra note 126 , at 6. 
describes a process for her selection. ${ }^{180}$ She need not have legal training. ${ }^{186}$ If the parties fail to agree upon an umpire for any reason, then the state Superior Court may appoint one in a summary action and set her hourly fee if the rate of pay has not been designated by the parties. ${ }^{187}$

The umpire's scope of authority is identical to that of an arbitrator and follows the Prima Paint Rule. ${ }^{188}$ An important modification under the NJADR Act is to vest in the umpire the power to grant provisional remedies as if she were an inferior state court operating under the state constitution. ${ }^{189}$ Since significant amounts of money could be tied up through these measures by the order of a legally untrained umpire, the court reviews and enforces the granting of provisional remedies in an expedited proceeding. ${ }^{190}$ Bestowing this remedial power on umpires is intended to reduce the amount of ancillary litigation over procedural matters that may develop in a dispute otherwise properly diverted to ADR. ${ }^{191}$

\section{Prehearing Procedures}

Prehearing procedures under the NJADR Act have been augmented to facilitate factual development sufficient to allow the correct application of substantive law. One modification of AAA rules is a provision allowing formalized discovery, but limiting it to oral depositions and the production of documents, all of which must be completed within sixty days after receipt of the demand for alternate resolution or the entry of a final order compelling alternate resolution. ${ }^{\mathbf{1 9 2}}$

Although both the time limit and the permissible methods of discovery are subject to expansion according to the umpire's discretion, ${ }^{193}$ such a rule seems to be an apt compromise. The procedure minimizes the escalating cost and frustration associated with discovery requests; ${ }^{\mathbf{1 9 4}}$

${ }^{185}$ See N.J. STAT. ANN. § 2A:23A-9(a) (West 1987).

186 There is no statutory requirement that an umpire have legal training.

187 See N.J. STAT. ANN. §§ 2A:23A-9(a)-23A-9(b) (West 1987).

188 See id. § 2A:23A-5(a); supra note 36 and accompanying text.

${ }^{189}$ See N.J. Stat. Ann. § 2A:23A-6 (West 1987).

190 See id. This provision was added to the NJADR Act at the insistence of the Governor's Office. See id. § 2A:23A-1, at 33 (Governor's Reconsideration and Recommendation Statement).

${ }_{191}$ See id. § $2 \mathrm{~A}: 23 \mathrm{~A}-6$, at 39 (Draftsman's Legislative History) (noting that neither the New Jersey Arbitration Act, the FAA, nor the UAA authorizes arbitrators to issue such orders).

${ }^{192}$ See id. $\S 2 A: 23 A-10(b)$.

${ }^{193}$ See id.

104 See supra note 65-66 and accompanying text; supra notes 112-17 and accompanying text. 
rather than depending upon the parties' voluntary cooperation with each other at a time when it may not be forthcoming, mandatory discovery will ensure a fair and equal opportunity to construct a case so that the umpire can better evaluate the claims. In some disputes presently subject to arbitration, discovery is essential to a fair contest on the merits. ${ }^{195}$ Recognizing the frequently realized potential for abusive delays in conventional discovery processes, however, the Act sharply limits its parameters. ${ }^{196}$ The goal is to provide some semblance of the factual development attained in litigation, but at a reduced cost.

Because the parties submit briefs to the umpire stating the factual and legal issues to be resolved, each party must undertake a detailed factual development of its case. ${ }^{197}$ The parties' submissions limit the matters to be resolved at the hearing, but supplementary briefs are permitted at the umpire's discretion. ${ }^{198}$ Unless the parties have access through discovery to relevant materials possessed by the other side, the briefs and subsequent findings by the umpire are likely to be incomplete, if not inaccurate. Furthermore, the ability of the umpire to fashion a more creative resolution of the dispute than the law allows is curtailed, because both the facts and the law relevant to the decision are limited to those covered by the briefs. Applicable law is set forth for the umpire and she is bound to adhere to it. In making her award, an umpire is compelled to consider only matters that the parties believe apposite. Finally, the briefs are more likely to present a balanced view of the dispute than would the "position papers" employed in the arbitration forum for the same purpose. ${ }^{180}$

The only technical rules of evidence applicable to dispute resolution under the NJADR Act are those relating to privilege. ${ }^{200}$ One small procedural exception that has a large substantive effect, however, is the power of the umpire to call an expert witness at the expense of the parties. ${ }^{201}$ This provision is particularly important because the umpire need not be an expert in the subject matter of the dispute, and, given

105 See Shell, supra note 104, at A3, col. 3. A survey of attorneys with experience in arbitration of construction disputes revealed that $80 \%$ wanted discovery by the arbitrator' to be permitted. See Statistical SuRVEY, supra note 126, at 6 .

${ }^{198}$ See N.J. Stat. AnN. § 2A:23A-10 (West 1987).

197 See id. § 2A:23A-11(e).

188 See id.

189 See Bayer \& Abrahams, supra note 8, at 31-32 ("The parties' briefs [in arbitration] do not discuss strengths and weaknesses. . . . Position papers of ten attempt to play on the lay-arbitrators' natural prejudices, using anything available to support the allegations.").

${ }_{200}$ See N.J. Stat. ANN. § 2A:23A-11(d) ("all statutes and common law rules relating to privilege shall remain in effect").

${ }^{201}$ See id. $\S 2 A: 23 A-11(f)$. 
the requirement that a decision be legally correct, will likely be chosen instead from among lawyers and retired judges in order to protect the award's finality. ${ }^{202}$

The expert witness provision appears to be aimed at retaining the benefit of expertise associated with the traditional arbitrator. ${ }^{203}$ The additional cost to the parties should be balanced against the fact that they would pay a premium fee for the most qualified arbitrators. ${ }^{204}$ The umpire can obtain expert knowledge as an additional aid in understanding the facts of the dispute just as a court might, thereby eliminating one line of attack upon the procedures by arbitration's proponents. If the witness has the bias feared by critics of arbitration, ${ }^{205}$ at least the parties have an opportunity to impeach the witness at the hearing; in contrast, the parties would find it awkward to impeach an arbitrator for bias before the conclusion of an arbitration. After the award, the standard of review places a heavy burden on the party seeking to prove bias. ${ }^{206}$ Finally, the expert witness provision may help to diminish selfinterested opposition to similar ADR reform in other states and at the federal level. After all, the present arbitrators would be most qualified to serve as experts.

Another measure intended to expedite the final resolution of a dispute is the option to combine into one consolidated action several different ADR proceedings between the parties, or an ADR proceeding and a court action. ${ }^{207}$ This method can help to eliminate costly and timeconsuming stay proceedings, as well as preclusion problems when claims are not resolved simultaneously. ${ }^{208}$

\section{The Award}

The most radical innovation offered by the NJADR Act is the requirement that the umpire submit a written opinion with her award, stating findings of fact and conclusions of law. ${ }^{200}$ The purposes of this provision, in conjunction with the requirement that the law be correctly

202 See Naiman, supra note 39 , at 3.

${ }^{203}$ See supra notes $106-07$ and accompanying text.

204 See Coulson, supra note 38 , at 681 .

${ }^{205}$ See supra notes 108-09 and accompanying text; see also Lasersohn, supra note $8, \S 11$, at 28 , col. 1 (stating that an arbitrator "has virtually unlimited power to decide a case submitted to him as he chooses, regardless of the facts, the provisions of the contract or the law").

${ }^{208}$ Under the Federal Arbitration Act, a disappointed party must prove the partiality or corruption of the arbitrator. See 9 U.S.C. $\$ \S 10(a)-10(b)(1982)$. This will be a difficult feat with no requirement of a transcript, findings of fact, or conclusions of law.

207 See N.J. STat. ANN. \& 2A:23A-3 (West 1987).

${ }^{208}$ See id. $\S 2 \mathrm{~A}: 23 \mathrm{~A}-3$, at 36 (Draftsman's Legislative History).

200 See id. § $2 A: 23 A-12(a),(e)$. 
applied, are to impart a high degree of predictability to ADR, to guarantee the quality of the decision by eliminating any temptation to compromise, and to facilitate subsequent judicial review. ${ }^{\mathbf{2 1 0}}$ The apparently solid foundation of this section provides promise for efficient procedures explicitly aimed at increasing predictable, quality results. ${ }^{211}$ Proponents of arbitration use this provision as an easy target. They argue that the NJADR Act compromises the very finality that motivates parties to choose ADR over litigation by facilitating review. By requiring adherence to substantive law, they suggest, persons without legal training are held to an extremely high standard, perhaps precluding them from serving as umpires. They also argue, most broadly, that it is an unnecessary legalization of the arbitration process. ${ }^{212}$

\section{Review}

The drafters of the NJADR Act insist that the provision for only a single expedited appeal from an umpire's decision ${ }^{213}$ improves upon the finality offered by arbitration, because arbitration may actually serve as a preliminary to litigation in many cases anyway. ${ }^{\mathbf{2 1 4}}$ AAA rules seek to enhance finality by obscuring the substantive basis of an arbitrator's decision; the NJADR Act accomplishes the same end by enhancing the substantive quality of the process while limiting the availability of review. Whether the total burden on the courts will be less than that inflicted by appeals from arbitration remains to be seen.

\section{CoNCLUSION}

In the real world of commercial disputes, comparative analyses of arbitration, litigation, and the new forum under the NJADR Act are irrelevant unless the parties actually choose the most efficient forum for

210 See id. § 2A:23A-12, at 47 (Draftsman's Legislative History).

211 See id.

212 See, e.g., Chambers, supra note 39, at 1, 20 (Some in the arbitration industry say that the NJADR Act's appeal provision would defeat the purpose of arbitration.); Naiman, supra note 39 , at 3 (The NJADR Act would discourage the use of nonlawyers as arbitrators, and would unnecessarily legalize the arbitration process.); see also Sterk, supra note 75, at 484 n.9 (The desire to maintain confidence in the system of arbitration serves as "an incentive for a resolution that seems equitable to the parties and a disincentive to consider factors extraneous to justice between the parties.").

${ }_{213}$ See N.J. Stat. ANN. § 2A:23A-13. But see id. § 2A:23A-13(c)(5) \& (e)(4) (an award can be modified or reversed if it is not in accordance with applicable law).

214 See supra note 66; cf. Standard Chlorine of Del., Inc. v. Leonard, 384 F.2d 304, 305 (2d Cir. 1967) ("Arbitration is often thought of as a quick and efficient method for determining controversies. Unfortunately, cases involving arbitration clauses sometimes are best remembered as monuments to delay because of the litigation and appeals antecedent to the actual arbitration."). 
the resolution of a particular dispute. When inserting a dispute resolution clause into their agreement, contracting parties probably will not strike a conscious balance between expeditious repose and qualitative results. Faced with a host of disincentives to litigation, they may initially choose arbitration as the most efficient process, only to regret the choice later and attempt to appeal their way back into the jurisdiction of the courts. This result is the most inefficient: arbitration becomes a mere preliminary to litigation.

If disputants understood the ramifications of process choice in all situations, however, they presumably would choose the formality of the courts over the informality of ADR, all else being equal. But because all else is not equal, contracting parties frequently opt to risk a virtually unreviewable decision that may be contrary to applicable law in order to achieve quick repose. When private parties of equivalent bargaining power enter the arbitration forum with eyes fully open in order to resolve routine commercial disputes, the futile appeals that may follow are merely a procedural inefficiency. The real problem is that the range of arbitrable claims has been steadily expanding in recent years, subsuming disputes of a nature that commercial arbitration was not designed to resolve. When a party is dragged unwillingly into a forum where claims need not be decided according to law, and the party never even contemplated that a particular type of claim would be arbitrated, the near futility of appeal raises disturbing substantive issues.

Rather than abandoning ADR altogether, a new ADR forum should be created for certain categories of disputes. ${ }^{215}$ Although striking a balance between quantitative and qualitative results has not been the goal of any particular constituency, ${ }^{216}$ such a reform has become imperative with the growth of the ADR movement and the concomitant concern that substantive principles are being ignored in favor of simple dispute resolution. Amending the Federal Arbitration Act and state statutes to require adherence to substantive law cannot accomplish this goal, because the informality of the arbitration forum is currently wellsuited to the resolution of simple commercial disputes. Thus, commercial arbitration and the procedures created by the NJADR Act need not be mutually exclusive. Rather, each forum has a discrete clientele: arbitration can resolve disputes in which relatively little is at stake between the parties and the issues are routine, and the NJADR Act's

216 See Fuller, supra note 60, at 389 ("[B]efore we demand of lay arbiters that they act like judges, we must place them in a context, and arm them with procedures, that will make it possible for them to do their job properly and still act throughout like judges.").

${ }_{216}$ See Brunet, supra note 8 , at 51. 
procedures can resolve disputes that are likely to involve statutory rights or unsettled principles of law.

The most incisive criticism leveled at the NJADR Act is that it needlessly legalizes the ADR process. While the term "legalization" carries negative connotations in the realm of ADR, in this context it connotes the best qualities of the judicial system: procedural regularity and adherence to known principles of substantive law. Perhaps the increased short-term costs are merely a necessary evil that must be endured in order to protect the quality of justice dispensed by ADR, preserve the normative benefits of litigation, and enforce the substantive policies underlying particular rights. If this assessment is accurate, then the long-term costs to society are likely to be reduced by relieving pressure on the court system and increasing confidence in ADR. The forum established by the NJADR Act would not necessarily lend any precedential value to decisions rendered there. Instead, it would reduce the incentive for parties to avoid the courts, because decisions would have to be made and remedies imposed according to law. The inherent limitation on the performance of this function is that parties may still opt for the arbitration forum when it is truly more efficient.

Nevertheless, both court administrators and legal scholars should greet the procedures of the Act with enthusiasm. Congress's consideration of these procedures as the proposed Federal Alternative Procedure for Dispute Resolution Act, and its possible adoption as a model statute by the Commissioners on Uniform Laws, indicates a perception that a gap exists in available modes of dispute resolution that is not unique to New Jersey. Indeed, with the legitimization of arbitration and its relatively unprincipled application by the nation's courts and legislatures as an alternative to adjudication, the need for reform has become manifest. The NJADR Act's innovative combination of substantive protection and procedural efficiency promises a satisfactory response. 